\title{
ابن الأنباري سيرته الذاتية وآثاره النوعية
}

\section{د. عبد الحكيم مُمُحَّ بادي}

كلية الآداب - جامعة مصراتة

\section{مقدمة: - مق}

الحمد لله رب العالمين، والصالاة والسلام على أشرف المرسلين وإمام المهتدين وخاتم

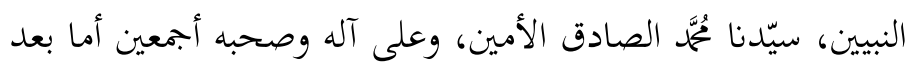

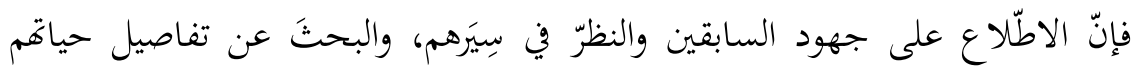
يُعَدُّ من الأمور الجليلة التي تربط حاضرنا بماضينا، وتمدّنا بزاد العِظة والعبرة والتدبّر، وتُشعرنا

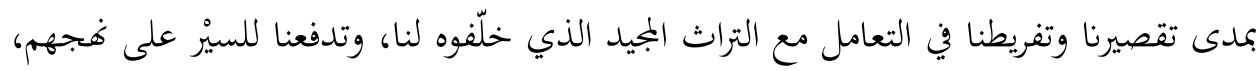
واتبّاع مَسْلكهم العلميّ القويم. هذا وقد آثرتُ دراسةَ شخصية الإمام (الأنباري - ابن الأنباري)(1)؛ لأني وجدتُ أنّ أنّ

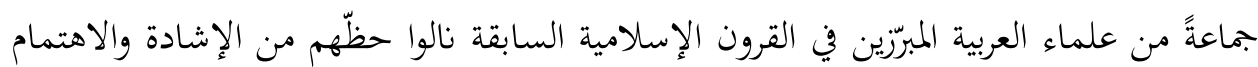

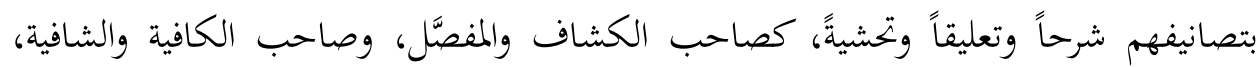
وصاحب الألفية والتسهيل، وصاحب البحر والارتشاف، وصاحب الشذور والمغني ... أما

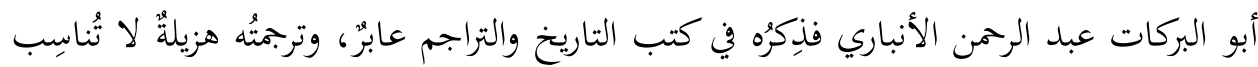
مكانتَه العلمية وتصانيفه النوعية؛ إذ تممل كثيراً من جوانب حياته وتمرّ على جوانب أخرى أخرى مرورَ

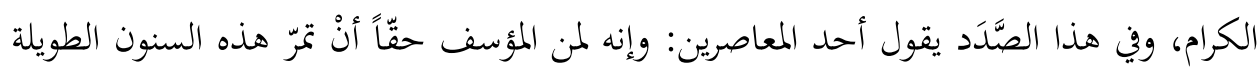

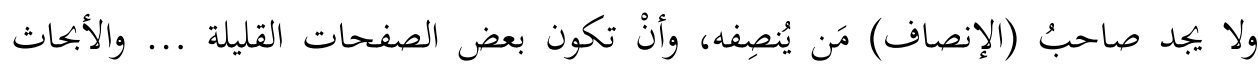

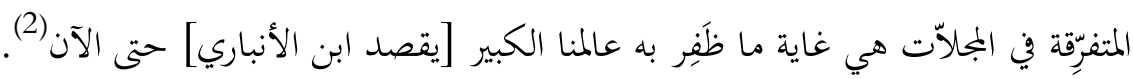

1- يُلِقِبِّه مُترجموه ومحِّقُو كتبه -أحياناً (بالكمال) و(الأنباري) وأحياناً أخرى يُكنّونه ب(أبي البركات) و(ابن الأنباري)، والأخيرة أشهر. 2- ابن الأنباري وجهوده في النحو لجميل علّوش، المقدّمة صرة 5-6 بتصرّف. 
وعليه فإنني سأنضمٌ إلى الذين كتبوا عن الشيخ الجليل، لعلّي أُثري شيئاً عن حياته

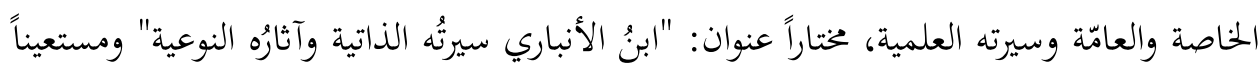

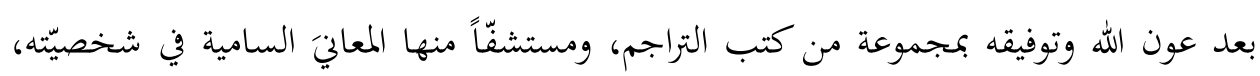

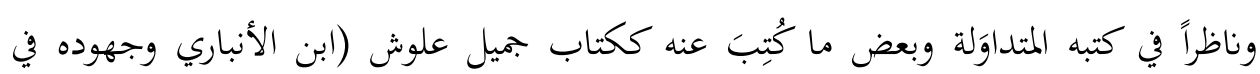

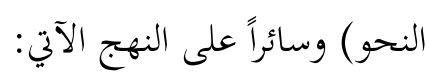

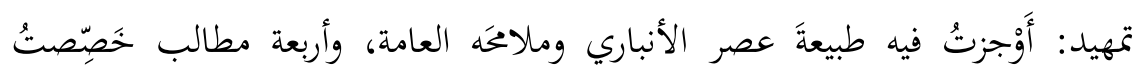

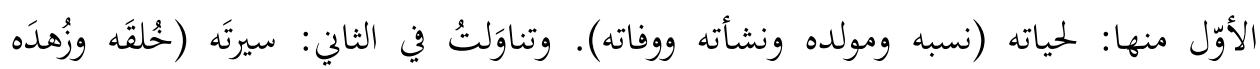

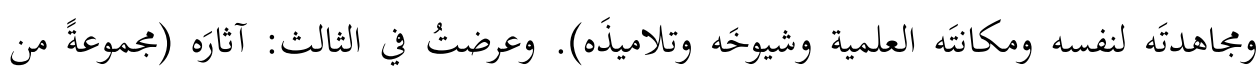

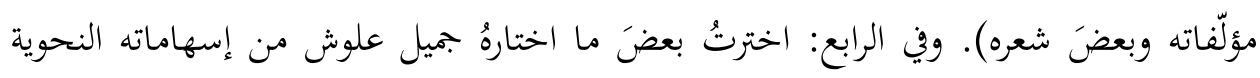

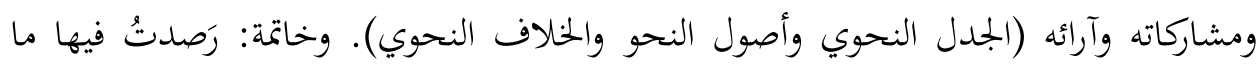
تَوصّلتُ إليه من ملاحظاتٍِ وفوائدَ.

\section{تمهيد: عصر ابن الأنباري}

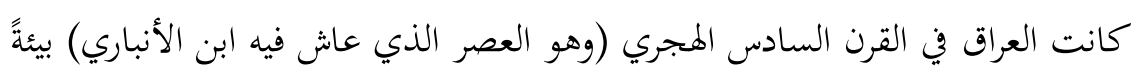

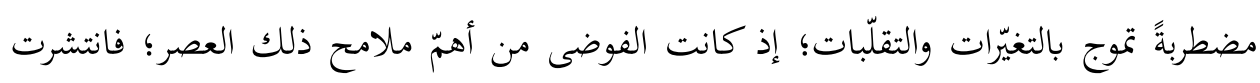

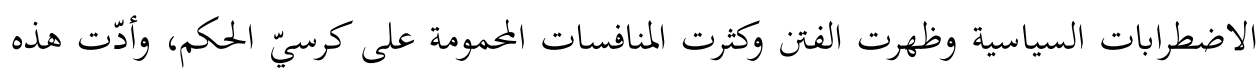

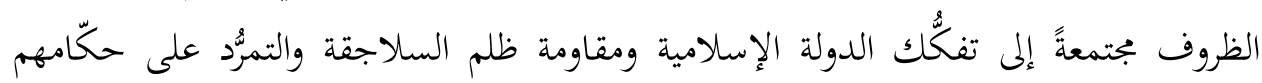

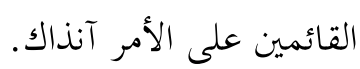

أمّا من الناحية الاجتماعية فقد سادت الطبقيّة الظلمة التي قسّمت الناس قسمينّ:

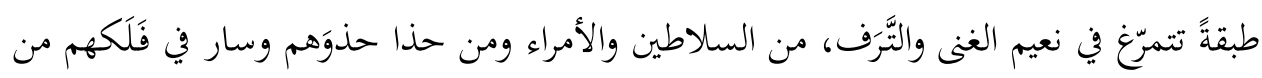

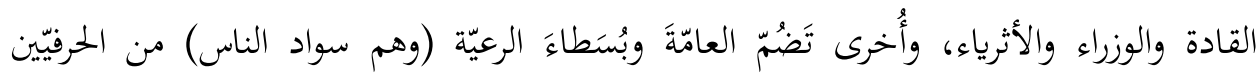

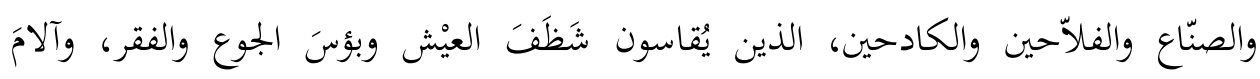
الاستبداد والضيْم. 
وعلى الرغم من وفرة الأموال في بيت مال المسلمين وتنوّع الموارد، بسبب اتّساع رقعة الدولة الإسلامية في تلك الآونة، فإنّ الفقرَ والمرض كانا متفشِّييْن بين الناس؛ لسوء توزيع

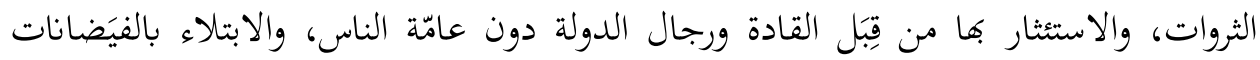

$$
\text { والكوارث الطبيعية .... إلخ. }
$$

ولقد أدّى سوء الحالة السياسية والاقتصادية -اللذيْن هما سببُ كلِّ انحراف- إلى

فقدان الأمن في هذا الزمان، وفساد الأخلاق وانتشار الجريمة، وتوفّر البيئة المناسبة لبروز الأفكار

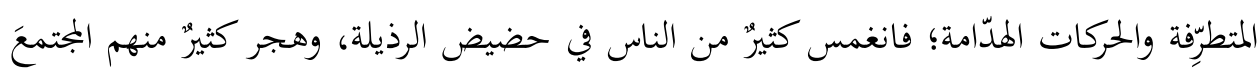
مُقبلين على حياة الزهد والتصوُّف، وهذا ما يبرِّر عزلةً ابن الأنباري ومَيْلَه إلى المتصوِّفة كحال

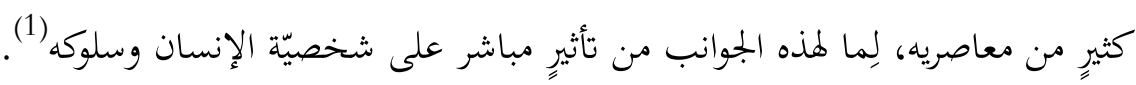
المطلب الأوّل: - مياته

\section{إلبمُهُ ونَسبُهُ:}

هو الشيخ الإمام كمال الدين أبو البركات عبد الرحمن (2) بن عُمَّمَ بن عبيد الله بن أبي

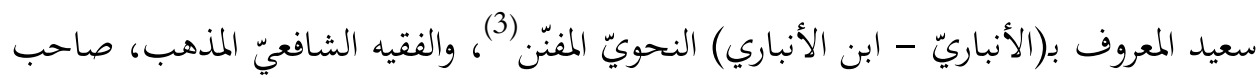
كتاب الإنصاف.

هذه السلسلة في نسبه هي ما عليه أغلبُ أصحاب التراجم، وإنْ وُجِد بعض التغيير الطفيف بين مؤلٍِِّ وآخرَ من تقديم الكُنية أو اللَّقَب، وقد خالَف بعضُهم في اسم أبيه أو جدِّه؛

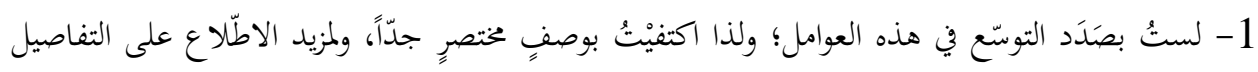

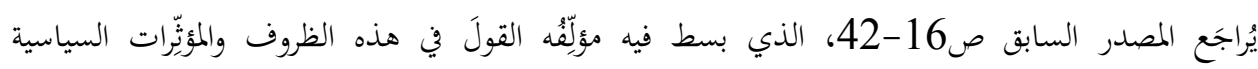
والاجتماعية والاقتصادية وما ترتّب عليها، إِستناداً إلى مصادره التاريخية: العربية والأجنبية.

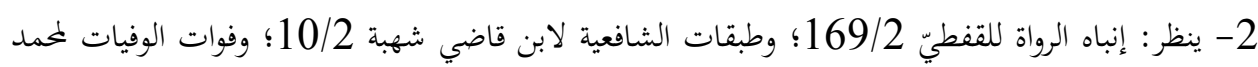
بن شاكر الكتبي 92/2؛ وروضات الجنّات للخوانساري 30/5. 3- ينظر: بغية الوعاة للسيوطيّ 86/2. 
فتاج الدين السُبْْيّ وصاحب هديّة العارفين يذكران بعد (عُبْيْ الله) (ابن مُصعَب)(1)، ويُضيف صاحب الأعلام لقب (الأنصاريّ)(2)، ويختصّّ ابنُ كثير بوصف أبيه ب(أبي السعادات) وتكرار (مُحَّمَ بن عبيد الله) (3)، أمّا ابن خلّكان والزركليّ (4) فيذكران أنّ أباهُ يُكنّى ب(أبي الوفاء)، ويزيد الأوّل (ابن الحسن بن سليمان) ويُلِقِبه بـ(الأنباريّ).

\section{مولده:}

وُلِد ابن الأنباريّ بالأنبار في ربيع الآخر(5) عام ثلاثة عشر وخمسمائة من هجرة

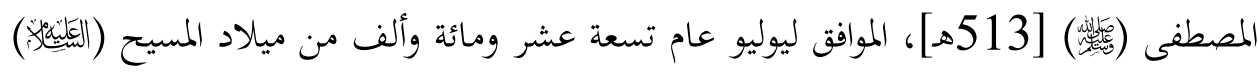

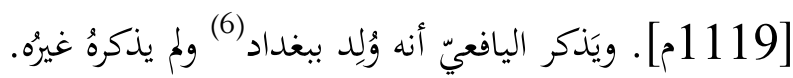
نشأته:

تربّى عبد الرحمن بن الأنباري في بيت علمِ ونَشأ نشْأةً صالحةً؛ فكان يسمع من أبيه في

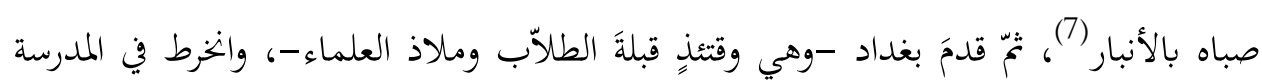
النظامية(8) ينهل من علومها ويستفيد من علمائها، وتَفقّهَ في المذهب الشافعيّ، وبرز في اللغة

1- ينظر : طبقات الشافعيّة الكبرى للسُّنكيّ 248/4. وهديّة العافين لإسماعيل البغدادي 2- ينظر : الأعلام للزركلي 104/4، والظاهر أنّ (الأنصاريّ) تصحيف في (الأنباريّ)، والله أعلم.

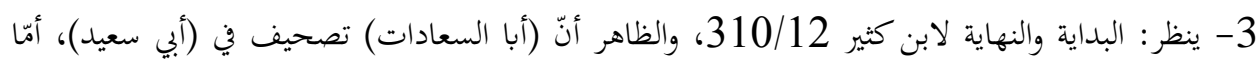
تكرار (يُحَّمَ بن عبيد الله) فهو ظاهر الخطأ، والله أعلم.

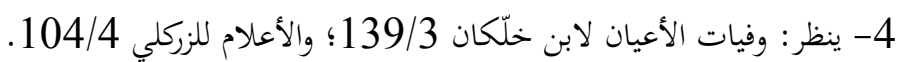

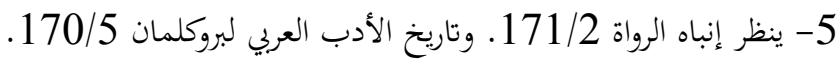
6- ينظر: مرآة الجِنان لليافعيّ ك- 408/3. 7 - 8نظر : بغية الؤعاة 86/2. 8 - 293/2 ينظر: فوات الوفيات 
والأدب حتى صار شيخ العراق مِن غير مُدافع (1)، تُشَدّد إليه الرحال من سائر الأقطار، ولم يترك بغداد قطُّ حتى وفاته (2). وقد تَوهم السيوطيُّ فذكر أنه دخل الأندلس تبعاً لابن الزبير في الصِّلة(3)، والجدير

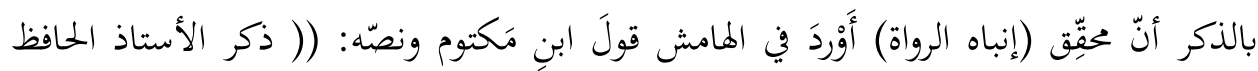

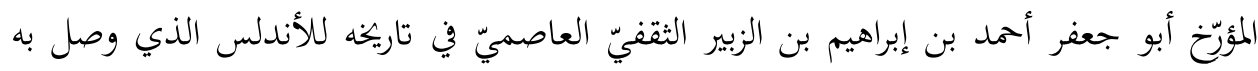

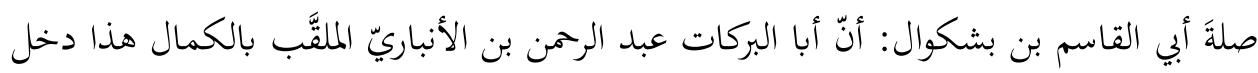

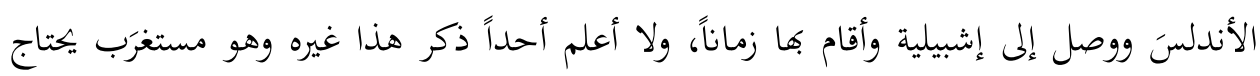

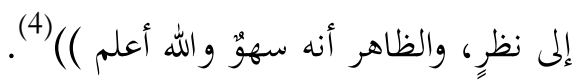
ومن استعراض النصوص السابقة يتبيَّن أنّ رحلتَه إلى الأندلس لمُ تَتَبت بنقلٍ صحيحٍ قاطع، ولقد توقَّف (جميل علّوش) عند هذه النقطة وأشار إلى أنه بذل جهوداً مضنيةً في التحقّق من هذا الخبر، بتتبُع المصادر التاريخية ومقارنتها؛ فتوصَّل إلى عدم اقتناعٍ بالرحلة، ووصفَها بالرحلة المزعومة، والراجح عنده أنّ الخبر قابلٌ للنفي والإثبات؛ لأنّ الأدلّة غيرُ كافيةٍ والحُججج غير قاطعةٍ؛؛ خصوصاً وأنّ صلةً ابن الزبير لمُ يُعثَر عليها كاملةً حتى الآن، ويُتركك الحكمُ القاطع للأيام، فلربمّا برز دليلٌ يؤيّد هذا أو ذاك (5). وبالنظر إلى ما سبق أستطيع أنْ أُؤيّد نفْيَ الرحلة من وجهين: الأوّل: أنّ السيوطيّ -رحمه الله- غير مُتحفٍٍِّ في نقل بعض الأخبار؛ لأنه ناقلٌ عن

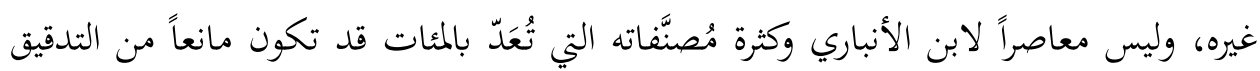

$$
\begin{aligned}
& \text { 1- ينظر : طبقات السبكيّ 248/4. } \\
& \text { 2- ينظر : إنباه الرواة 170/2. } \\
& \text { 3- ينظر: بغية الوعاة 86/2. } \\
& \text { 4- إنباه الرواة 171/2. } \\
& \text { 5- ينظر: ابن الأنباري وجهوده في النحو ص48-46-56. }
\end{aligned}
$$




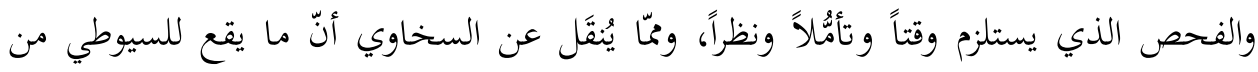
التحريف والتصحيف إنما هو بسبب عدم مزاحمته للفضلاء في دروسهم واستبداده من بطون

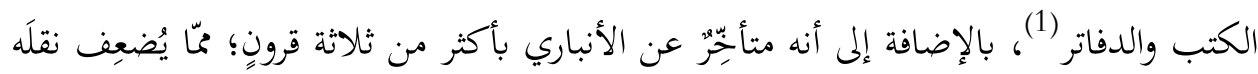
والثقةَ بخبره في هذا السياق تحديداً. الثاني: أنّ عالماً جليلاً بقيمة ابن الأنباري -وإِنْ كان كما قيل عنه: بأنه معروف

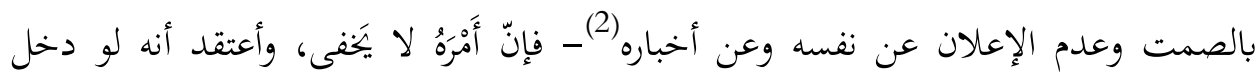

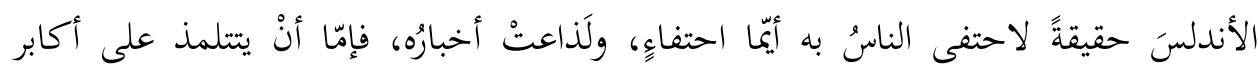

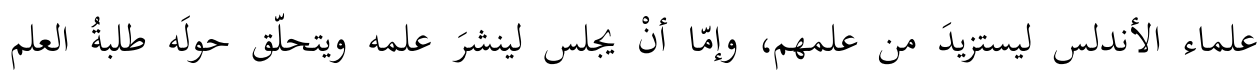

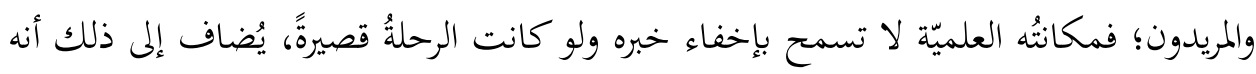

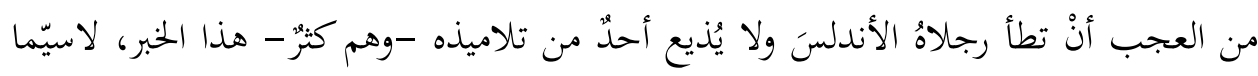

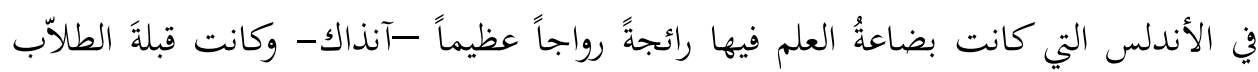
يؤمّوها من كلّ حدبٍ وصوْب، فدلّ هذا على انتفاء الرحلة، والله أعلم.

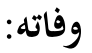

انقطع ابنُ الأنباري في أواخر أيامه عن الناس، ولنِمِ بيتَه مشتغلاً بالعلم والعبادة والإفادة

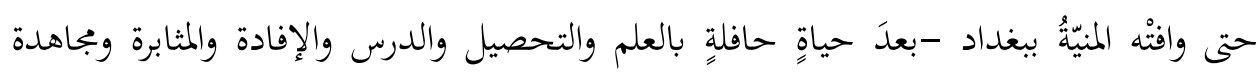

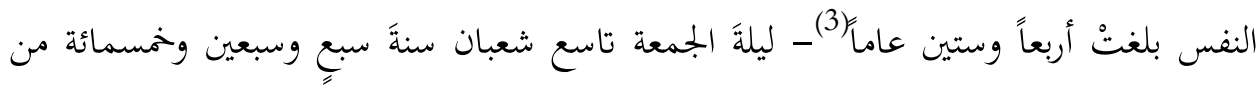

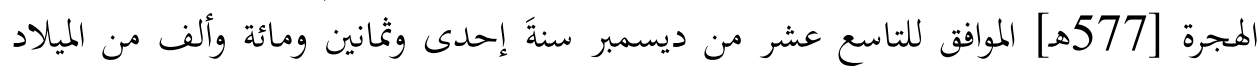

1- ينظر: ابن الأنباري وجهوده في النحو ص169؛؛ ويراجع الضوء اللامع لأهل القرن التاسع للسخاوي

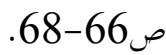
2- ينظر: ابن الأنباري وجهوده في النحو ص86-68-87.

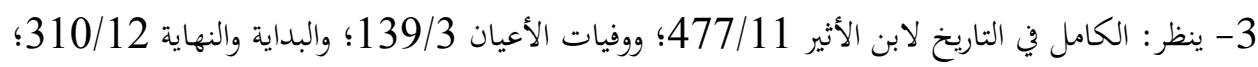

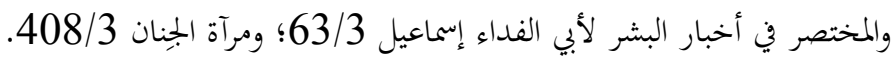


[1181م] [1)، ودُفِن في اليوم نفسه بباب أبرز بتربة الشيخ أبي إسحاق الشيرازي، زرمَمه الله تعالى رمةً واسعةً. نسبته إلى الأنبار:

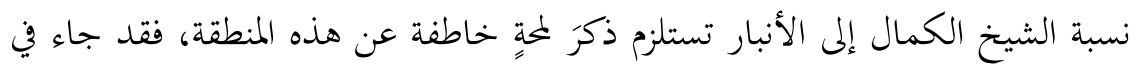

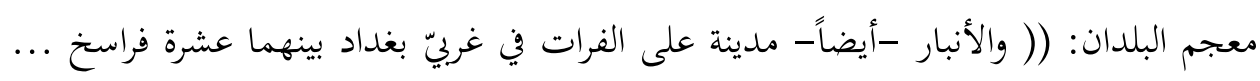

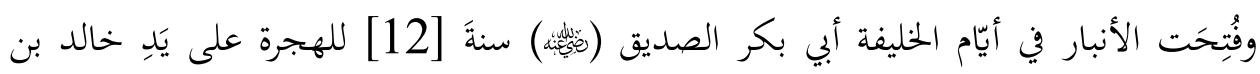
الوليد () (2) الأنبار وجاء في دائرة المعارف الإسلامية: (( الأنبار مدينة على الضفة اليسرى لنهر الفرات في الشمال الشرقي للعراق جنوبي خطٌّ طول

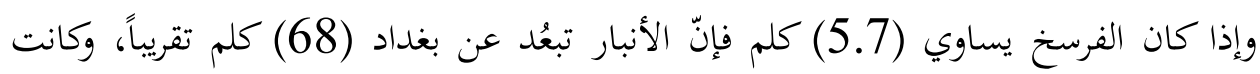

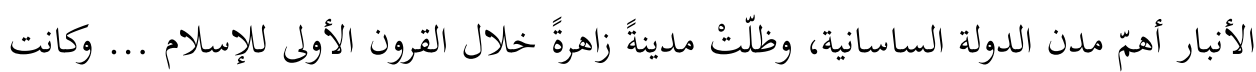

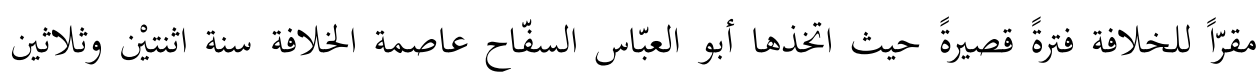

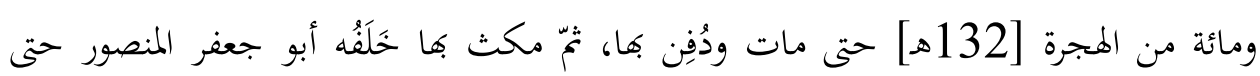

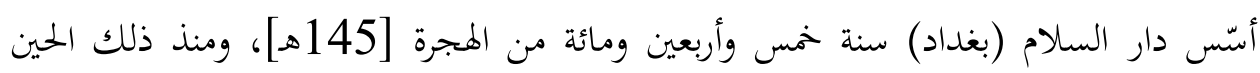

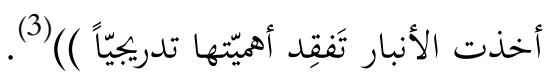

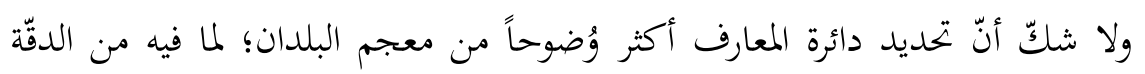

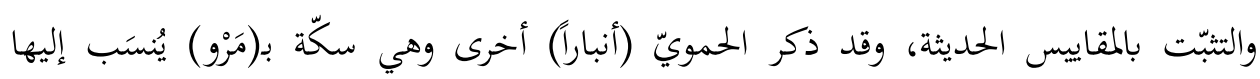

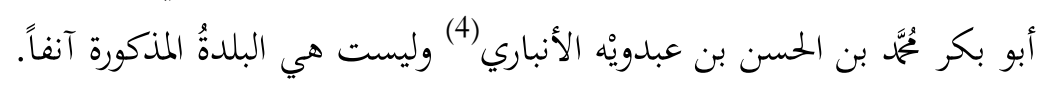

1 - ينظر: دائرة المعارف الإسلامية 4/3.

2- معجم البلدان لياقوت الحمويّ 305/1 305، دارة المعارفية 306.

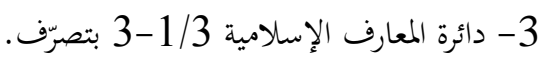

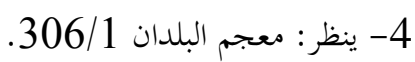


هذا وقد برز من الأنبار جماعةٌ من الفضلاء والعلماء في كلّ فنٍّ أ، ومّّن اشتهروا بلقب

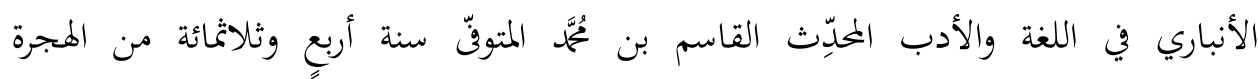

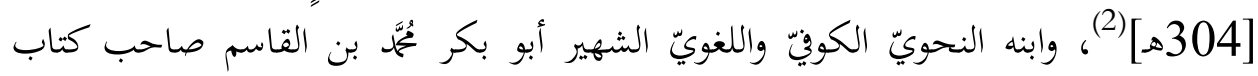

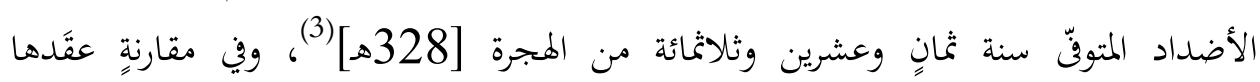
الخوانساري بينَه وأبي البركات قال: (( والفرق بينهما أنه [يعني أبا بكر] كان منحصرَ البراعة في

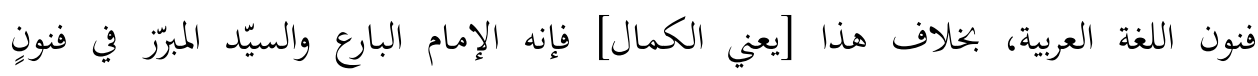
شنّى () (4) (4) ويبدو أنّ أبا البركات لم ينسَ مسقطَ رأسِه فألّف كتابَه (تاريخ الأنبار)، وأظهرَ فيه انتماءهُ لعلمائها الأفذاذ، حيث احتفى بسلفِهِ الكبير (أبي بكر) على الرغم من كونه كوفيّاً وهو بصريّ، ومع هذا يخصِّص له ترجمةً من أوسع الترجمات في كتابه (نزهة الألبَاء) (5).

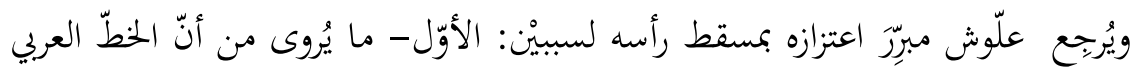

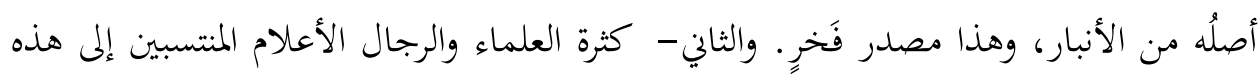
البلدة (6)

$$
\text { المطلب الثاني: سيرته }
$$

\section{خُلُقه:}

جميع مصنفات التراجم تُثني على ابن الأنباري وتقف منه موقف الإجلال والإكبار؛

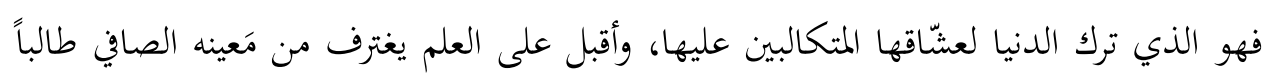

$$
\begin{aligned}
& \text { 1 - ينظر : الأنساب للسمعاني 212/1. }
\end{aligned}
$$

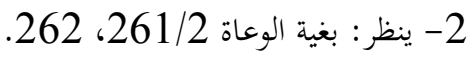

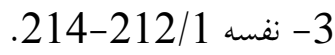

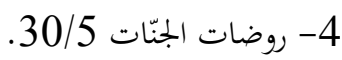

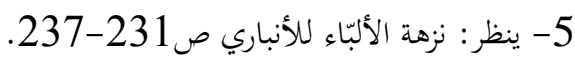

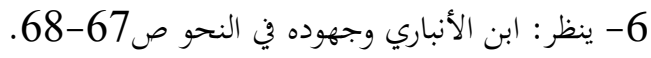


وجةَ الله الكريم، ورَضي من الدنيا بالعَفاف والكفاف، فلمّ يتلبّس منها بشيء، وهو يسير بين

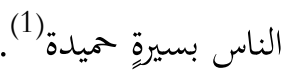

وأَوْرَد السُّبكيّ قولَ الموفَّق عبد اللطيف: (( لمُ أرَّ في العُبّاد والمنقطعين أقوى منه في

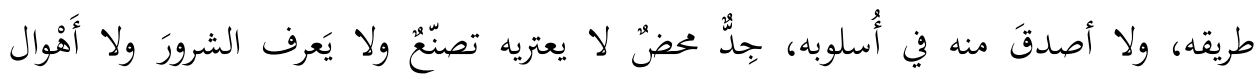

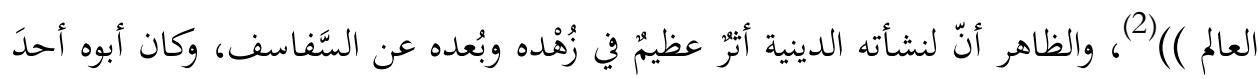

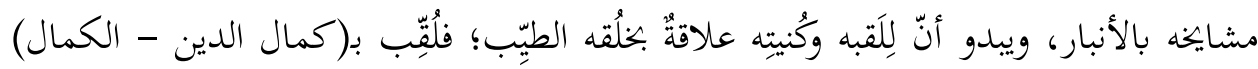

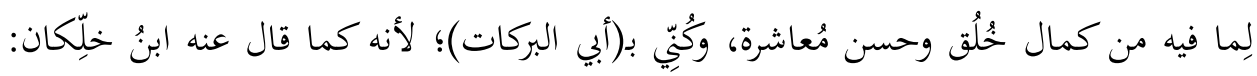

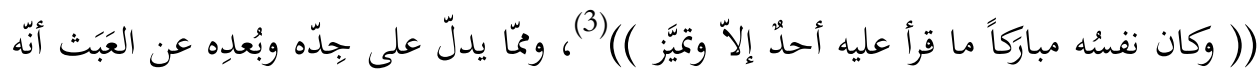

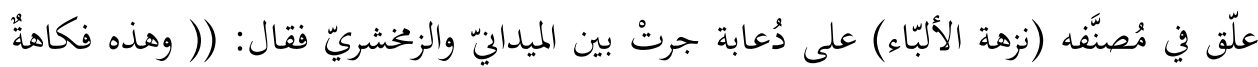

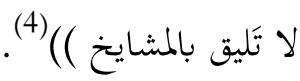

ولم يمنعْهُ انقطاعُه عن الناس في أواخر أيّامه عن فتحح الباب على مصراعيْه لطلبة العلم الوافدين إليه الراغبين في التزوُّد من علمه؛ فكان فتحُ بابِه واستقبالُه لهم وإبابتُه لرغبتهم أكبرَ

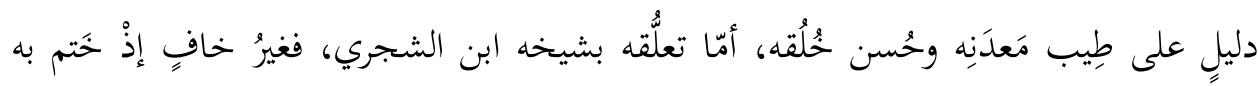

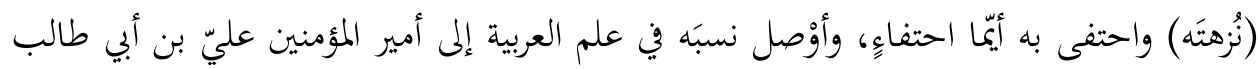

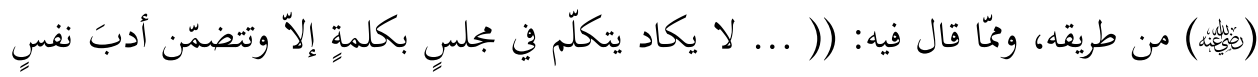

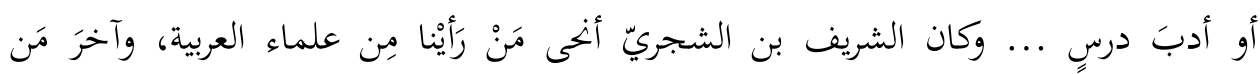

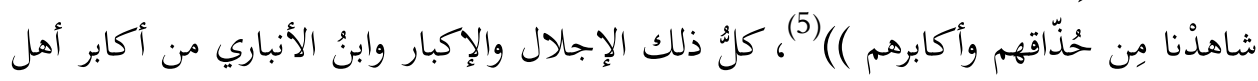
السنّة، وشيخُه القائم بوظيفة نقيب الطالبين بالكرخ نيابةً عن الطاهر مِن أقطاب المذهبب

$$
\begin{aligned}
& \text { 1- 139/3 ينظر : وفيات الأعيان }
\end{aligned}
$$

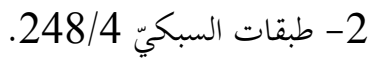

$$
\begin{aligned}
& \text { 3- وفيات الأعيان 139/3. }
\end{aligned}
$$

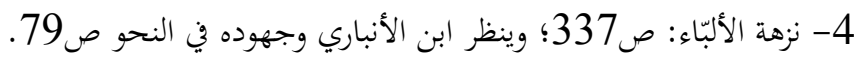

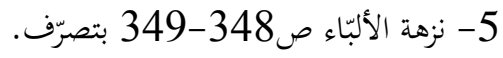


الشيعيّ في عصره؛ وفي هذا دليلٌ صارخ على سماحة النفس والتسامُح والرُقّيّ في التعامل مِن قِبَل العالِميْن الجليلين.

\section{زهذهُ وتصوّفه:}

لم يُعرَف عن أبي البركات عبد الرحمن بن الأنباريّ في سيرته وحياته الخاصّة سوى

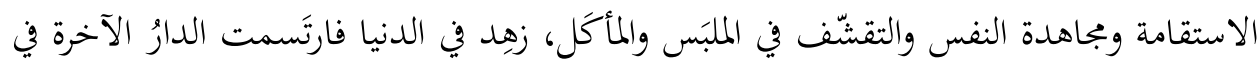
عقله وقلبه، ورغِبَ عن الناس فما رَغبوا عنه، شَقِيَ يومَه لِيسعََ في غدِده -وكذلك العقلاء-

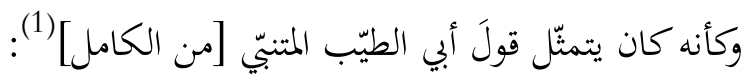

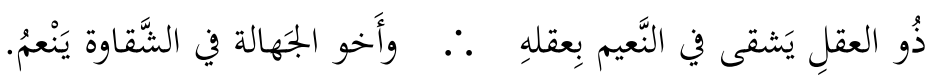

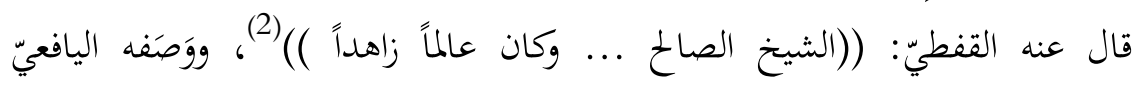

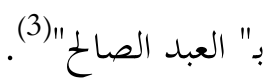

وقال السُبكيّ: (( وله الوَرَع المتين والصلاح والزُّهد )(4)، وكتب الحافظ ابن كثير:

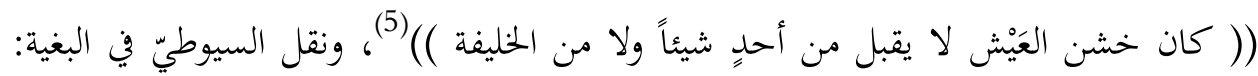

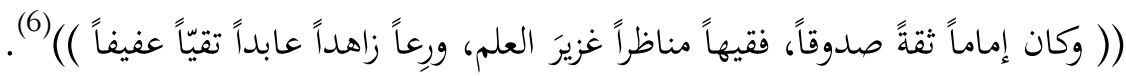

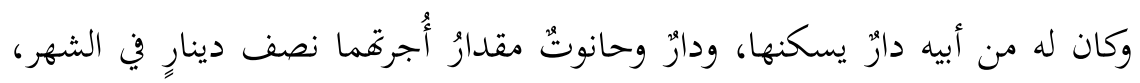

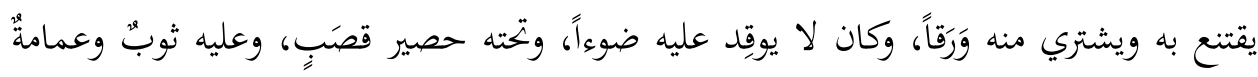

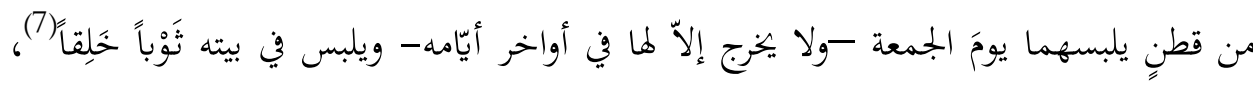

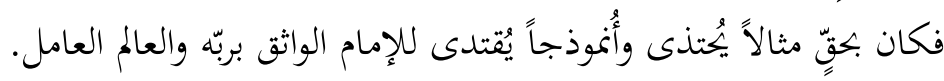

$$
\begin{aligned}
& \text { 1- شرح ديوان المتنبيّ للبرقوقي 251/4. } \\
& \text { 2- إنباه الرواة 169/2 بتصرّف. } \\
& \text { 3- مرآة الجِنان 408/3. } \\
& \text { 4- طبقات السبكي 248/4. } \\
& \text { 5- البداية والنهاية 310/12. } \\
& \text { 6- بغية الؤعاة 86/2. } \\
& \text { 7- ينظر : الطبقات الكبرى 248/4. }
\end{aligned}
$$


ويبدو من السرد التاريخيّ للعصر الذي عاش فيه ابن الأنباري أنّ سبب انقطاعه عن

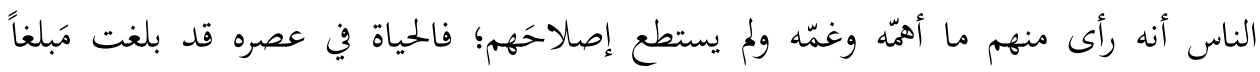

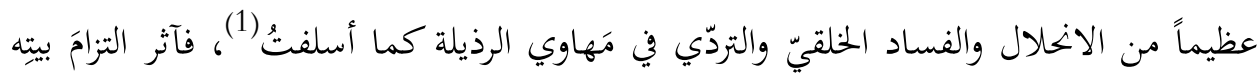

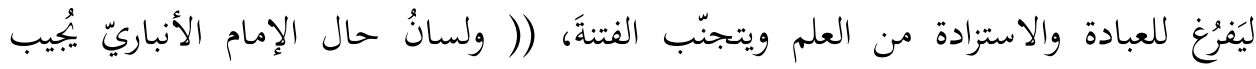

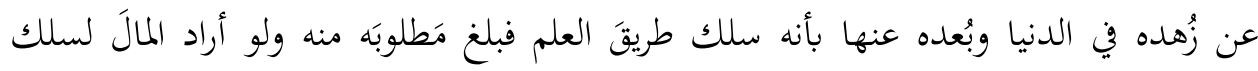
سبيلَه () (2) أمّا الحديث عن تصوّفه فغير مُصرَِّح به، ولكنه قد كرّس نفسَه للعلم والعبادة، وكان

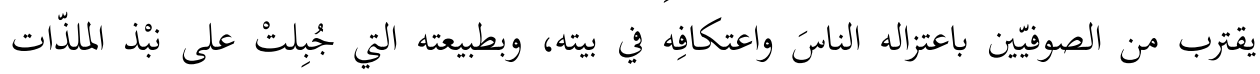

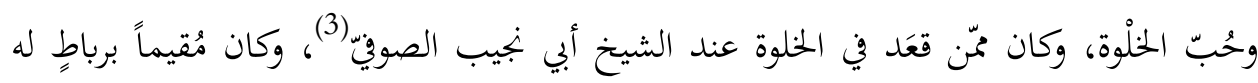

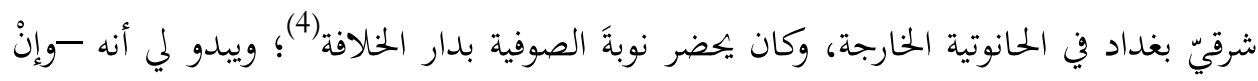

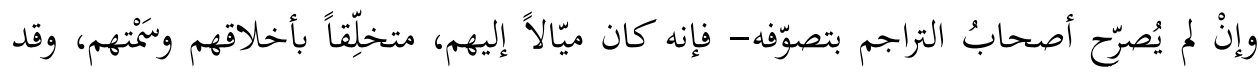

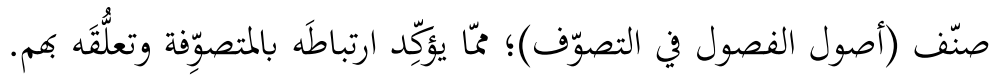

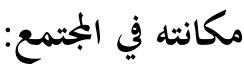

ولقد بلغ من اهتمام الناس به عامّةً ومن طلاّبه ومُريديه خاصةً، أنْ لقبّوه بـ(الكمال)

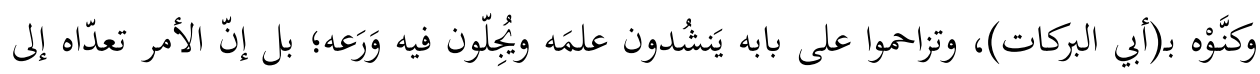

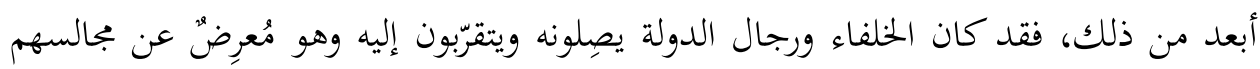

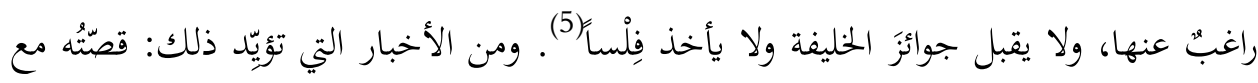

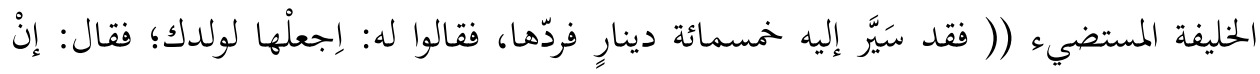

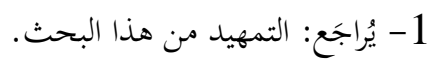

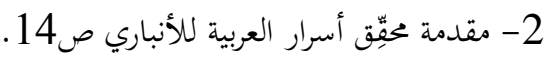

$$
\begin{aligned}
& \text { 3- ينظر: طبقات السبكي 248/4. } \\
& \text { 4- ينظر: إنباه الرواة 170/2؛ والبداية والبكية والنهاية 310/12. } \\
& \text { 5- ينظر: البداية والنهاية 310/12. يناه }
\end{aligned}
$$


كنتُ خلقتُه فأنا أرزقُه ())(1)، وتُبيّن هذه القصّة ما كان يتمتّع به الرجلُ من خُلُقِق نَبيلٍ وعفافٍ

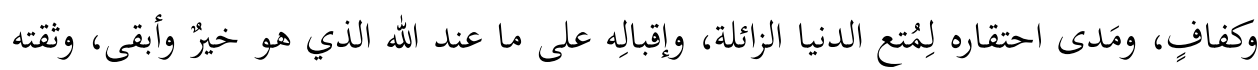
الكبيرة بربّه واعتداده بعلمه.

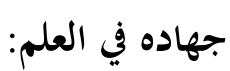

قبل الحديث عن مكانة ابن الأنباري العلمية لا بدّ من ذكرٍ سريعٍ للمدرسة النظامية

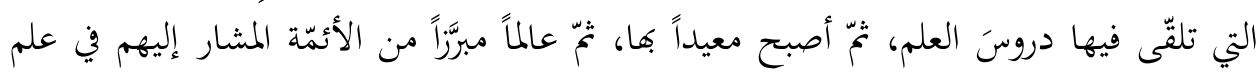
النحو (2)

المدرسة النظاميّة ببغداد: أنشأها وزير السلاجقة (نظام الملك) الذي عُرِف بمئله إلى

العلم وتقريب العلماء، ولم تكن نظاميّة بغداد الأولى من نوعها؛ ولكنها نالت شهرةً فائقةً، فقد درّس فيها كبارُ العلماء، منهم: الإمام أبو حامد الغزالي، والإمام الشيرازي وغيرهما، وتخرج منها علماءُ أفاضل نشروا لواءَ العلم كابن الأنباري، وتختصّ هذه المدرسة بضخامة البناء واتساع الفِناء

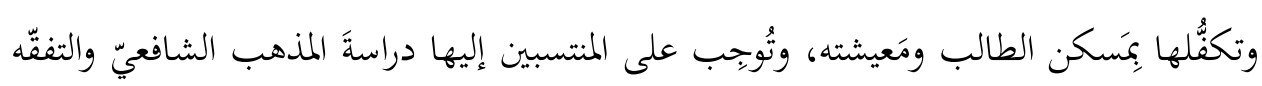

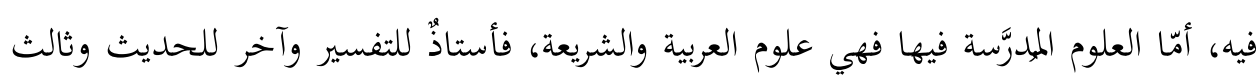

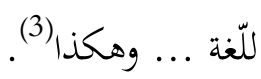
تبدأ رحلةُ ابن الأنباري مع العلم والقرطاس والقلم منذ أنْ قَدِم بغداد في صباه، والْتحقق بالمدرسة النظامية وتفقّه على مذهب الإمام الشافعيّ على يد (ابن الرزّاز) حتّى برع وحصّل طرفّاً

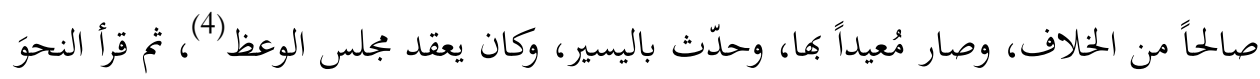

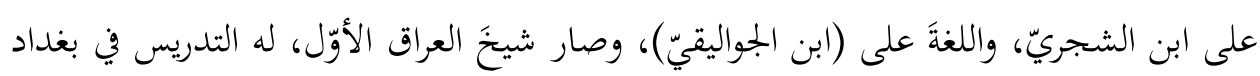

$$
\text { 2- 1 - طبقات السبكيّ 248/4. }
$$

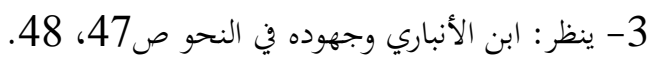

$$
\text { 4- 293/2 ينظر: فوات الوفيات }
$$


والرحلة إليه من سائر الأقطار (1)، وروَى كثيراً من كتب الأدب ومن مصنّفاته، والمقصود بالأدب

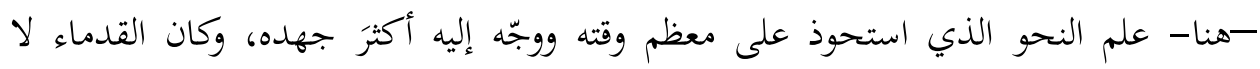
يُفرِّقون بين علم الأدب بمعناه التخصّصيّ الذي نعرفه الآن وهو النتاج الشعريّ والنثريّ وما يتعلّق كمما مِن نقدٍ وتحليلٍ ووصفٍ وتفسير ...، وبين الأدب بالمعنى العام الذي يشمل علوماً متباينةً،

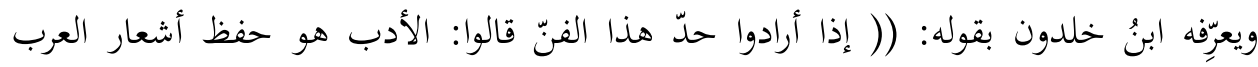

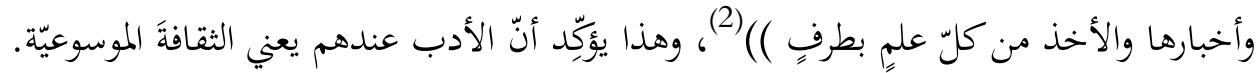
هذا (( وقد أقرأ ابنُ الأنباريّ الناسَ العلمَ على طريقةٍ سديدةٍٍ وسيرةٍ جميلةٍ من الوَرَع والمهجاهَدة والتقلّل والتنسّك )(3)، ولمُ يزل على هذه الحال حتّى لَزِم بيتَه وتفرّغ للتصنيف

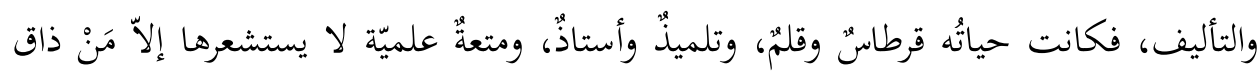
حلاوةً العلم، فما عَرف جسدُه الراحةَ ولا قلمُه الفتورَ؛ بل سَيْروةٌٌ متواصلةٌ من الإبداع والعمل الدؤوب، عقلٌٌ يُفكِكر، وذاكرةٌ تُملي، وقلمُ يستجيب فيَنسابُ على الدفاتر؛ ليُخرجَ في النهاية عُصارةَ علمِ وفكٍِ راقِ، كُتِب له البقاءُ على مرّ الأزمان.

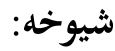

تلقّى ابنُ الأنباري العلمَ على مجموعةٍ صالحةٍ من أفاضل علماء عصره في النظامية

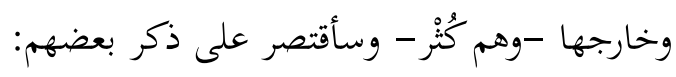

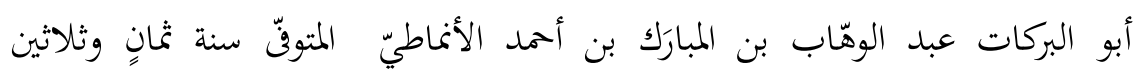

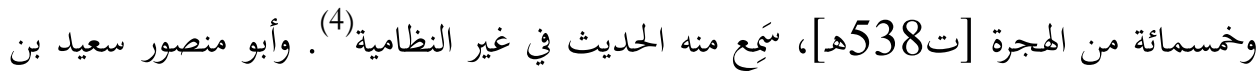

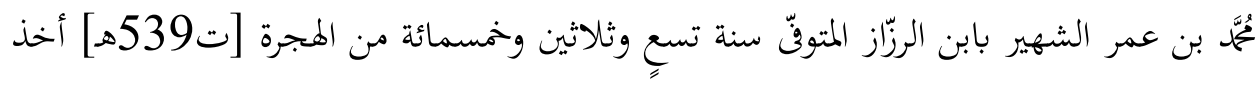

$$
\begin{aligned}
& \text { 1- ينظر : طبقات السبكيّ 248/4. } \\
& \text { 2- مقدّمة ابن خلدون 553/1. } \\
& \text { 3- 3- إنباه الرواة 170/2. } \\
& \text { 4- ينظر: طبقات ابن قاضي شُهبة 148/4. }
\end{aligned}
$$


عنه الفقه في النظامية، وهو من صفوة أشياخه(1). وأبو منصور مُحَّمَ بن عبد الملك بن الحسن بن

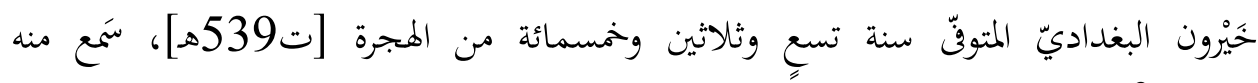

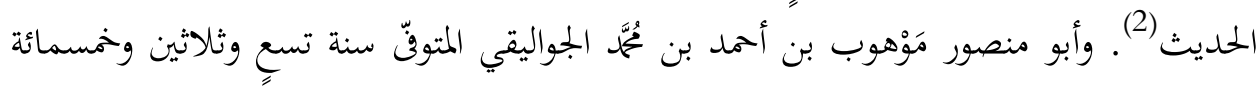

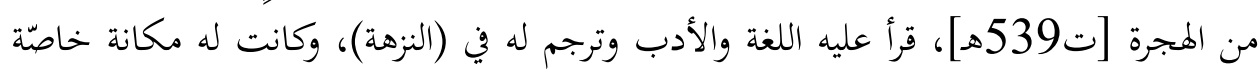

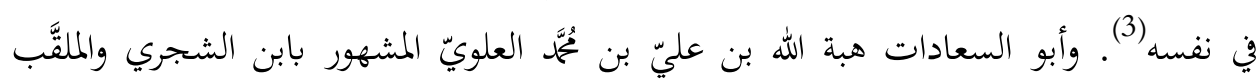

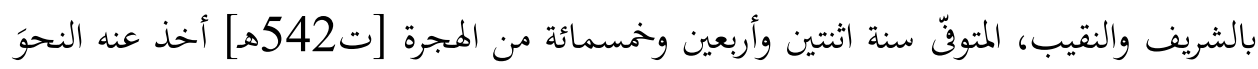

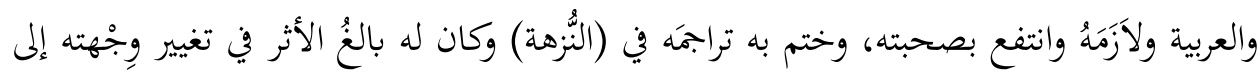
علم النحو، حتى بَرع فيه، ولم يكن ينتمي في النحو إلاّ إليه (4).

\section{تلاميذه:}

تصدّر الشيخ ابن الأنباري للتدريس بالمدرسة النظامية بدايةً، ثمّ واصل الإفادةً في بيته

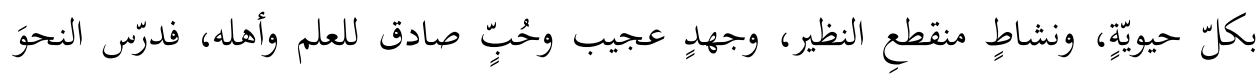
واللغةَ، وتَبحّر في العلم فقصدهُ خلقُ كثيرٌ صاروا علماء، وما قرأ عليه أحدٌٌ إلاّ وتميّز، كما نقل ذلك ابنُ خلّكان، ووصَفه بالبركة وذكر أنه لقِيَ جماعةً منهم؛ ولكنّه لمُ يصرّح بهم (5) -ولْيتَه فَعَل!!-- ومَّن رَوَى عنه: الحافظ أبو بكر تُحَّه الحازميّ، والقاضي أبو المحاسن عمر بن عليّ، وابن

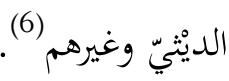

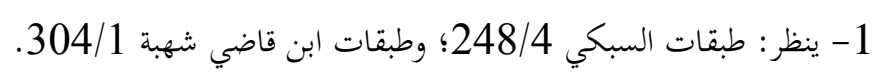

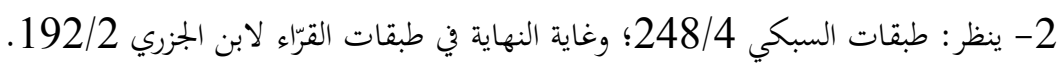

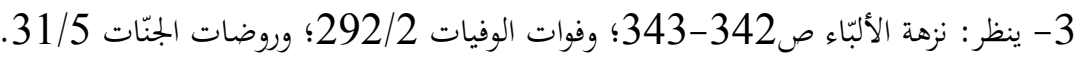

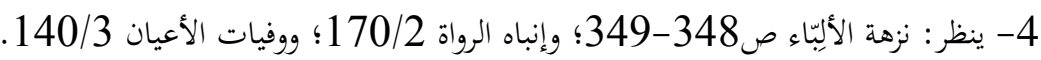

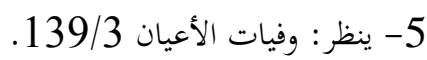
6- ينظر: طبقات السبكيّ 248/4؛ ينطيات الاعيان وفوفيات الأعيان 488/1. 


\section{المطلب الثالث: - آثاره}

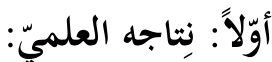

تميّز ابن الأنباري بغزارة نِتاجه وتنوّعه؛ فقد صنّف في أصول الفقه وفروعه، وعلم

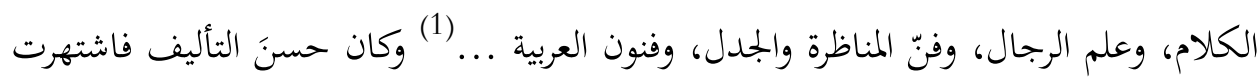

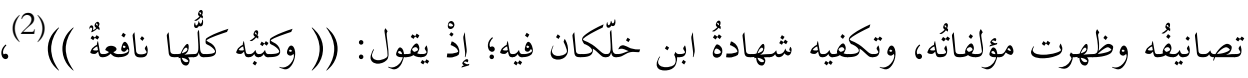
وقد تلقّاها العلماء مِن بعده بالقبول والشرح والدرس وأشاروا إليها في تضاعيف كتبهم.

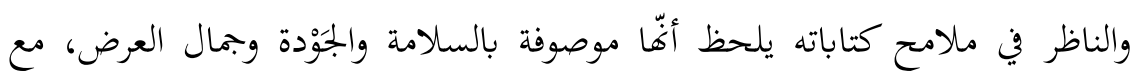
قدرةٍ على المناظرة والحِجاج العقليّ بالمنطق والدليل والإقناع وسطوع الحهجّة، أمّا أُسلوبَه فهو

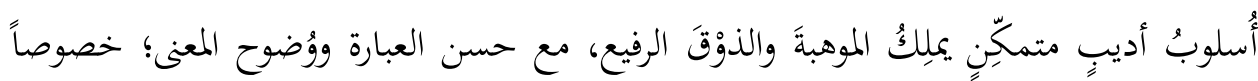

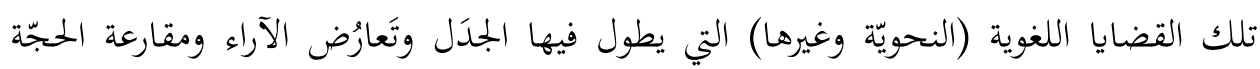

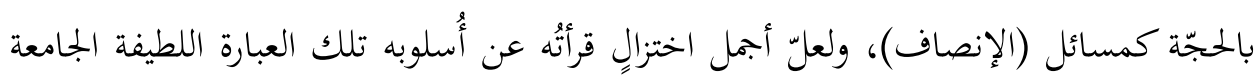

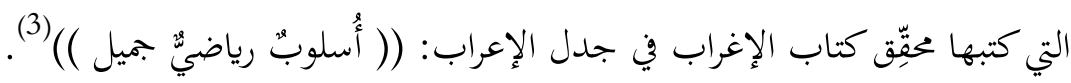

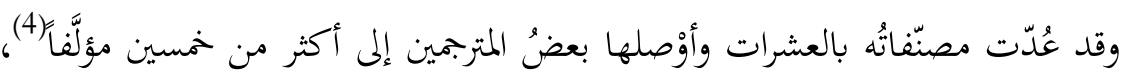
وأَوْرد ابنُ قاضي شُهبة في طبقاته قولَ الموفَّق عبد اللطيف: (( له مائة وثلاثون أكثرها نهوُ وبعضُها في الفقه والأصول والتصوّف والزهد )(5)، ويبدو أنه عَدّ الرسائلَ الصغيرة وتحقيقَ بعض

بعض المسائل كتباً، مثل: (تصرّفات لَوْ) و(كتاب في يَعْفُونَ) و(مقترَحَ السائل في: وَيْل امِّه) (6).

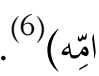

$$
\begin{aligned}
& \text { 1- ينظر : مقدمة أسرار العربية ص14. } \\
& \text { 2- وفيات الأعيان 139/3. } \\
& \text { 3- مقدمة الإغراب في جدل الإعراب ص22. }
\end{aligned}
$$

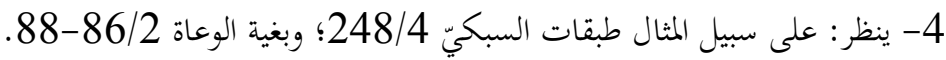

5- طبقات الشافعية 11/2.

6- ينظر: على سبيل المثال مقدمة محقّق أسرار العربية ص14-112-19. 


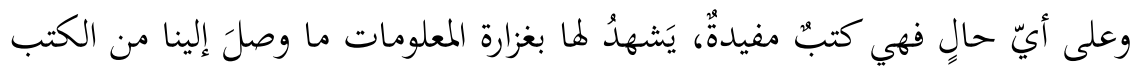

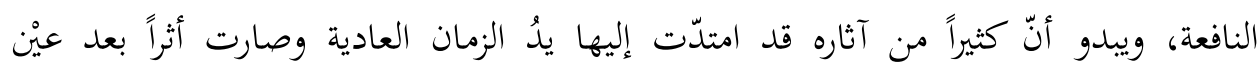
- كحال كثيرٍ من تراثنا الضائع - ولعلّ الله يُيَسِّر ظهورَها يوماً.

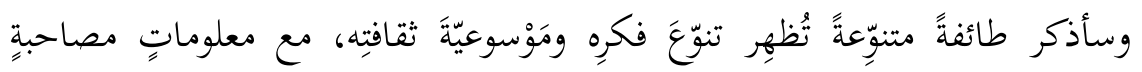

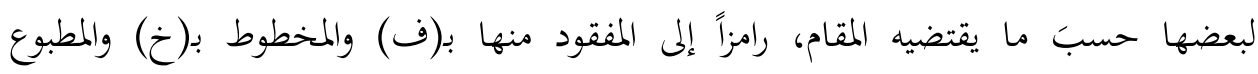
بـ(ط) بـ لإبراز مجهوده الجبّار في خدمة العلم عموماً، وعلوم العببية خصوصاً:

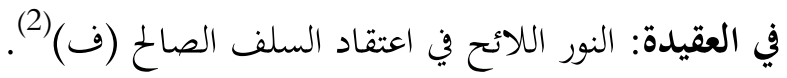

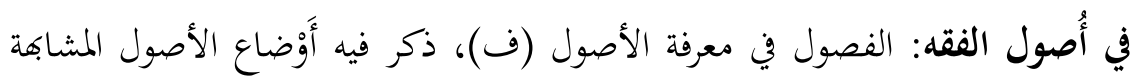
لأصول الفقه (3). في الفقه الشافعيّ: بداية المداية في الفروع (ف) ألّفهُ في المذاهب (4)، وهداية الذاهب في معرفة المذاهب (خ) صنّفه في المذهب الشافعيّ المان.

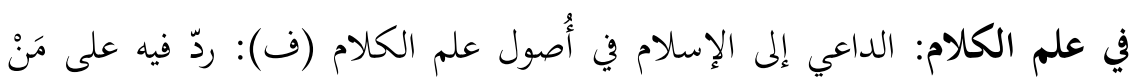

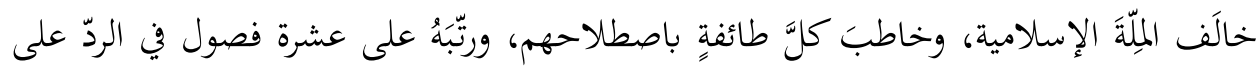
مَن أنكر الحدوثَ والصانع، والردّ على الثنويّة والطبائعيّين والمنجِّمين ومَن أنكر النبوةَ والمجوسَ

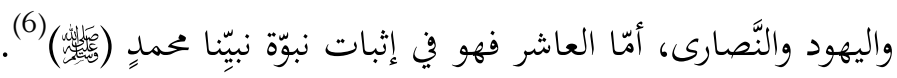

1- اعتمدثُ في بيانات (لمخطوط والمفتود) على ما استقصاهُ جميل علّوش في كتابه (ابن الأنباري وجهوده في

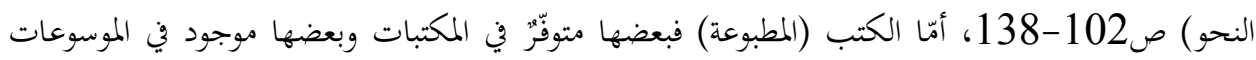

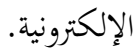
2- 2- ينظر: طبقات السكي 284/4؛ وهديّة العارفين 520/1.

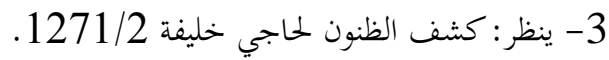

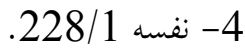

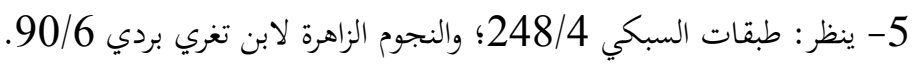

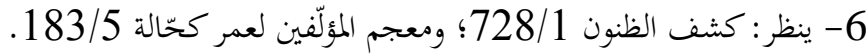


في المنطق: الجُمَل في علم الجحل (ف)(1). ونَجْدة السُوّوّال في عُمدة السؤال (ف)(2). في علم المصطلح: الاختصار في الكلام على ألفاظ تدور بين النُّّار (ف) (3).

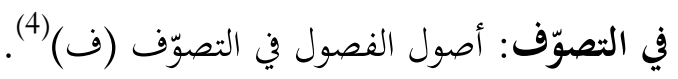

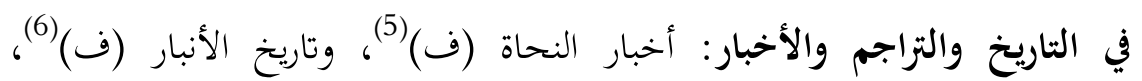

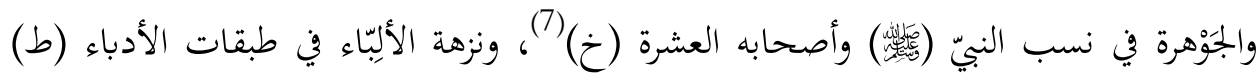

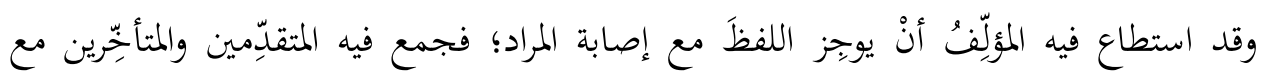
صِغَر حَجمِه، ووُصِف بأنه مفيدُ جِدّاً(8).

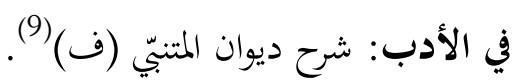
في العَروض والقافية: شرح المقبوض في علم العَروض (ف)(10). والموجز في القوافي ${ }^{(11)}(b)$

في التعليم: الحضّ على تعليم العربية (ف) (12).

1- ينظر: طبقات ابن قاضي شهبة 11/2؛ وروضات الجنات 31/5.

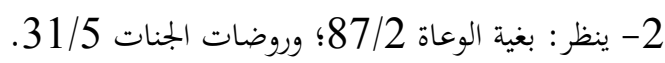

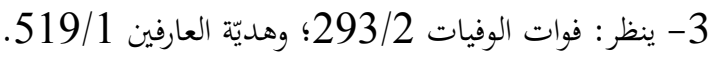

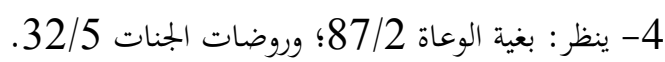
5- ينظر: بغية الوعاة 87/2.

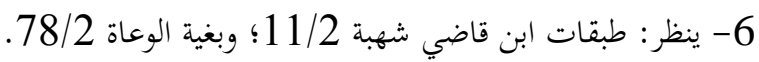

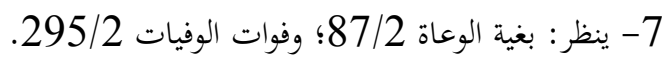

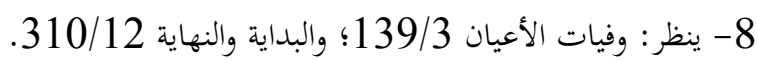
9- ينظر : فوات الوفيات 295/2.

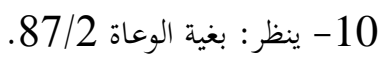

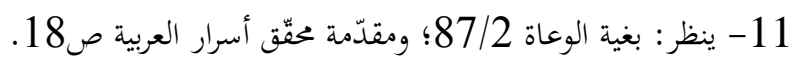

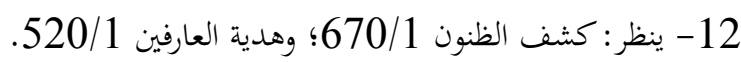




\section{في البلاغة: اللمعة في صنعة الشعر(ط)(1).}

في اللغة: حِلْية العقود في الفرق بين المقصور والممدود(ط)(2). والزهرة في اللغة

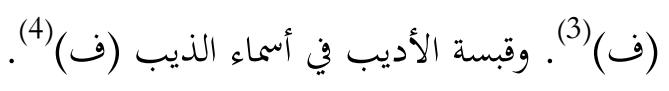

في النحو وأصوله: أسرار العربية، وهو مِن أحسن الكتب التي تبحثث في العبلّة

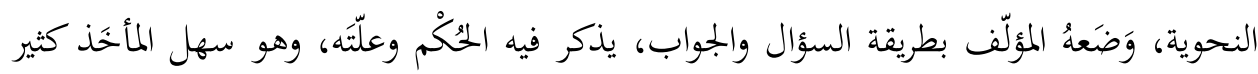

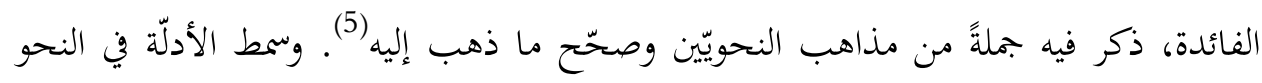
(خ) (6). والإغراب في جدل الإعراب، وقد رسم فيه المؤلَّف خطّةً محكَمةً لقواعدَ وقوانين تحُّم

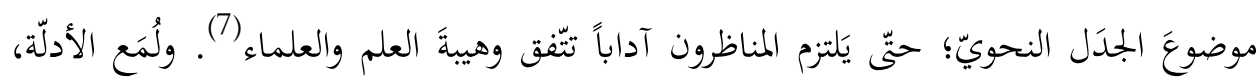

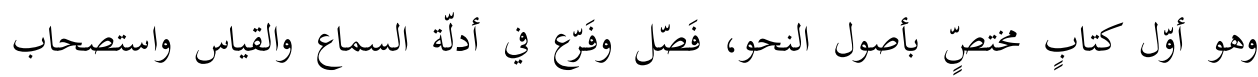
الحلال

في الخلاف النحويّ: الإنصاف في مسائل الخلاف، يُعَدّ أشهرَ كتب المؤلِّف في النحو

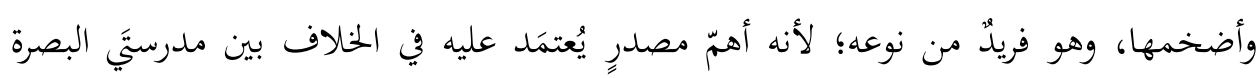

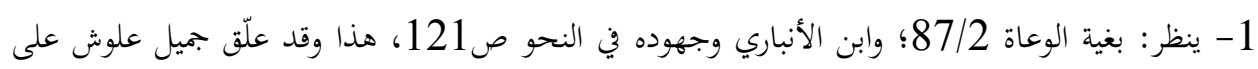

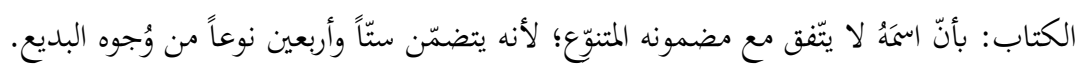

$$
\text { 2- 20ن ينظر فوات الوفيات 294/2. }
$$

3- ينظر: بغية الوعاة 87/2؛ وخزانة الأدب للبغدادي 156/5، وفئات البيها: ((قال ابن الأنباري في الزاهر:

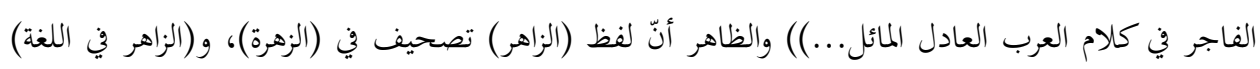
من كتب أبي بكر مُحَّمَ بن القاسم الأنباري، والله أعلم.

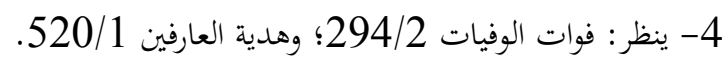

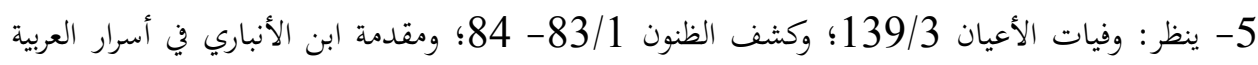
ص2. 6- ينظر: هدية العارفين 520/1؛ وتاريخ الأدب العربي لبروكلمان 172/5.

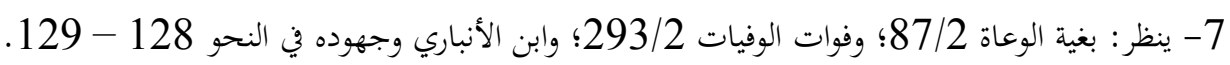

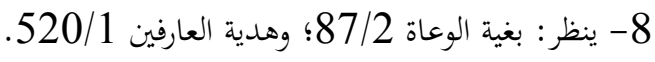




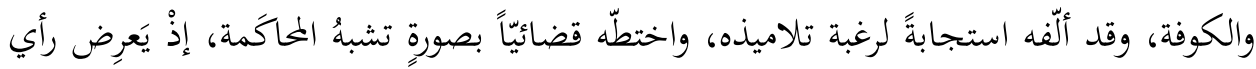

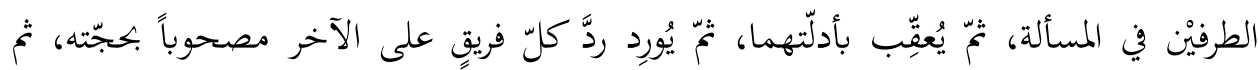

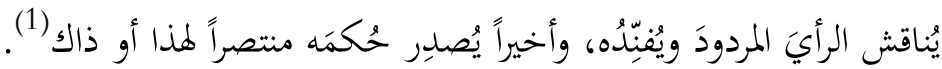

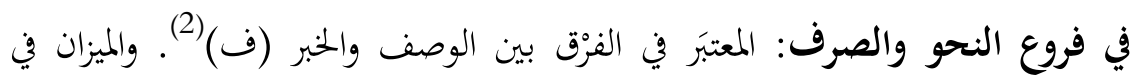

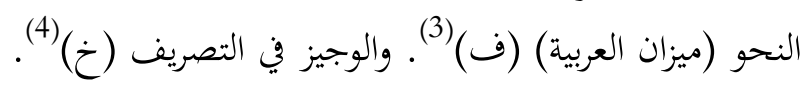

ثانياً: شِعره:

يصعُب الحكمُ على مدى شاعريّة الأنباري إذا ما نظرُنا إلى النَّفَ الضئيلة من شعره،

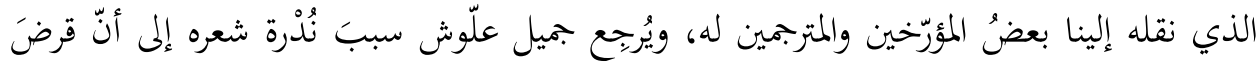

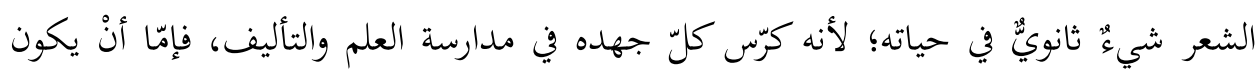

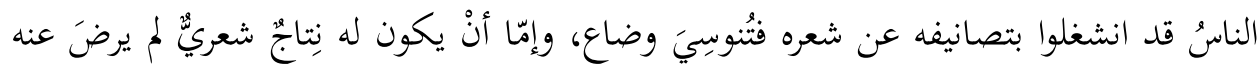

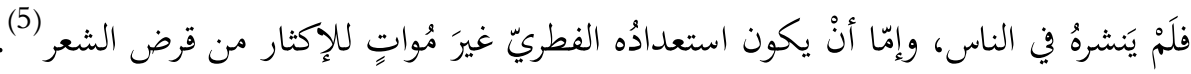

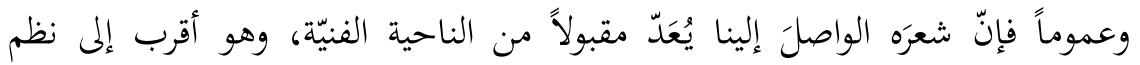

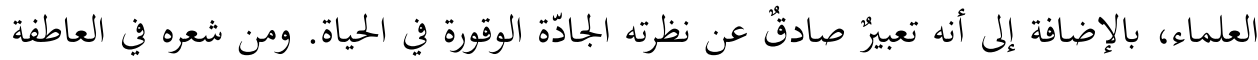
-وهو جِّدّ- [من البسيط] (6):

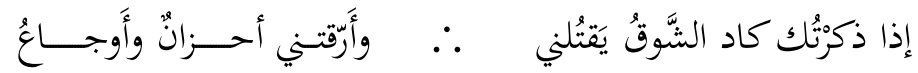
وصار كُلّي قُلوباً فيك داميسةً

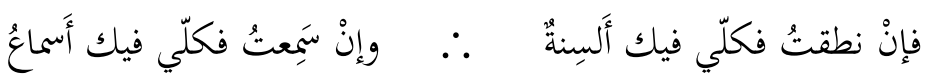

1 - ينظر: وفيات الأعيان 139/3؛ وبغية الوعاة 87/2.

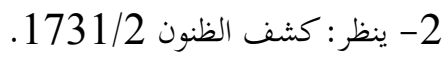

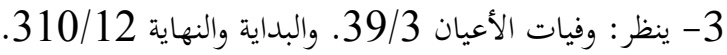

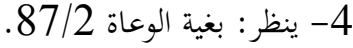

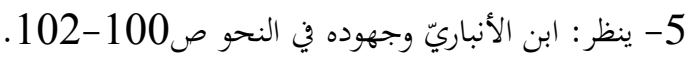

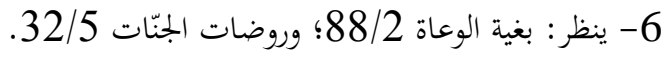




\section{ومن شعره في الوعظ والزهد [من الطويل](1):}

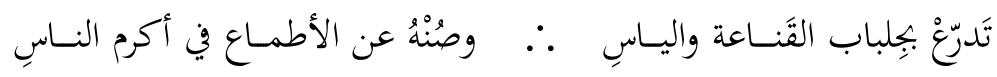

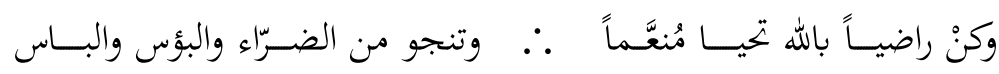

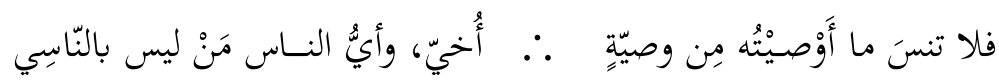

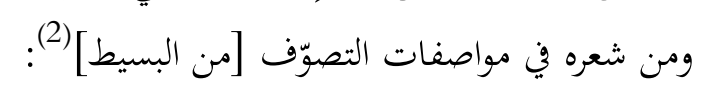

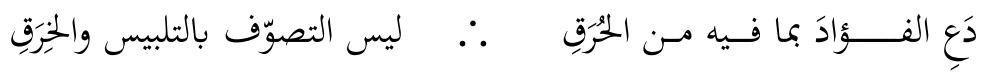

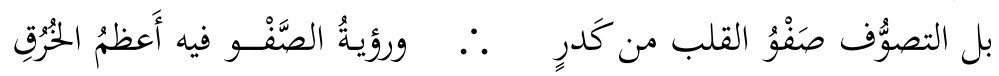

ومن شعره في الحثّ على طلب العلم والرفعة من شأن العلماء[من الكامل] (3):

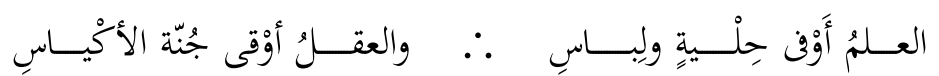

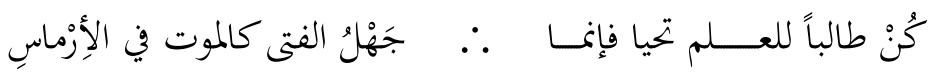

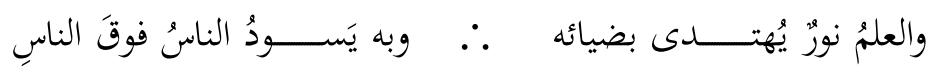

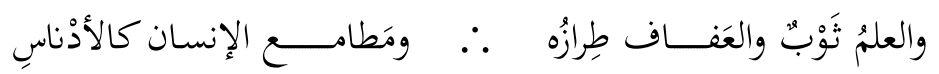

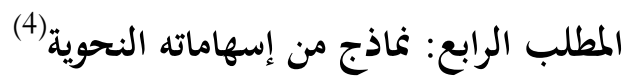 أوّلاً: إسهامُه في أصول النحو:}

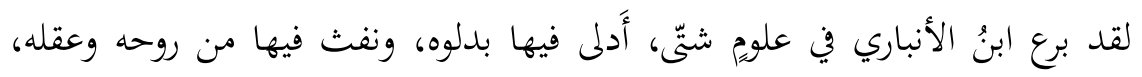

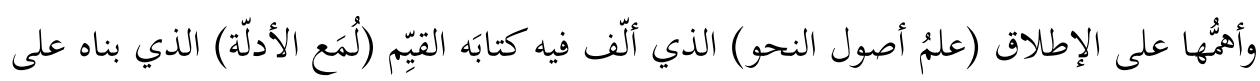

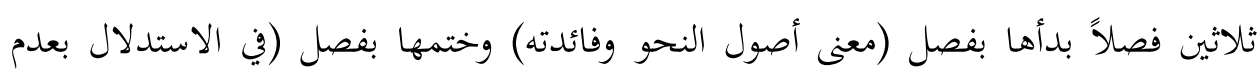

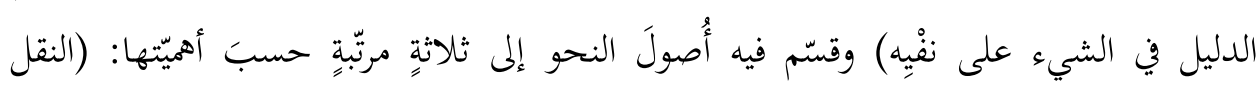

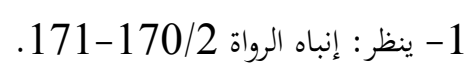

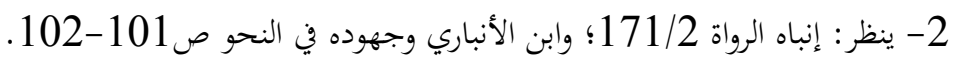

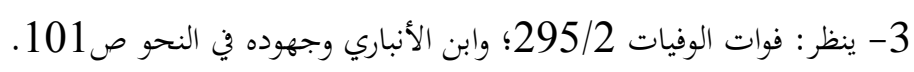

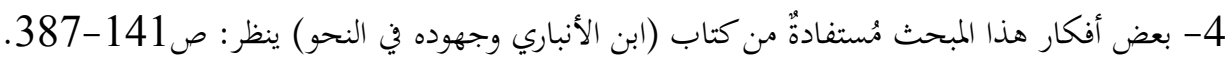


والقياس واستصحاب الحال)، دائراً بالنحو في فَلك الفقه، حيث اقتبس مصطلحاتِه وتقسيماته ونظامَه العام من كتب أصول الفقه، وحوّله من علمِ معتمٍٍِ على النقل والرواية إلى علمٍ يتّصل

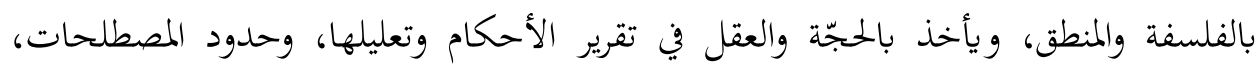
والنزوع إلى التأويل والتصوّر المجرَّد. والمتتبِع لمسيرة علم أصول النحو يرى لِلْوَهلة الأولى أنّ ابنَ الأنباري قد سُبِق بمحاولاتٍ

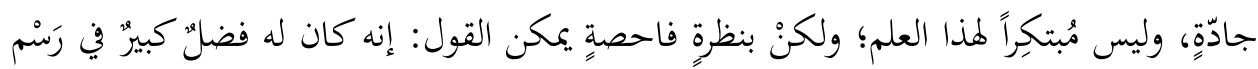

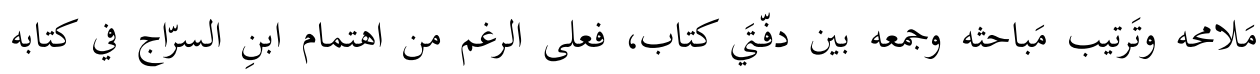
(الأصول)، بالقياس، فإنّ كتابَه لم يحمل ملامح علم الأصول، وإنما جمع مسائلَ سيبويه ورتّبها

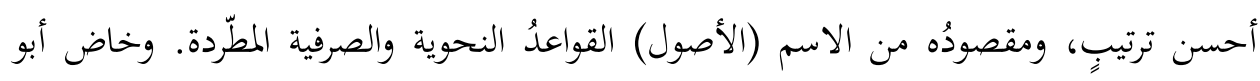
عليّ الفارسي في بعض مسائل هذا العلم في إطار شغَفه الكبير بالقياس والتوسّع فيه؛ ولكنه لم

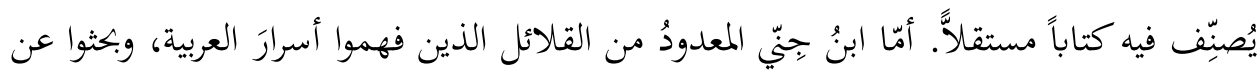

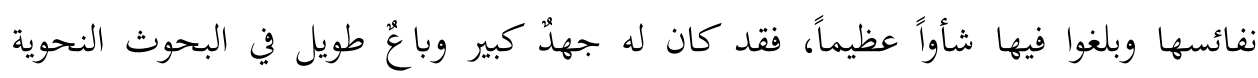

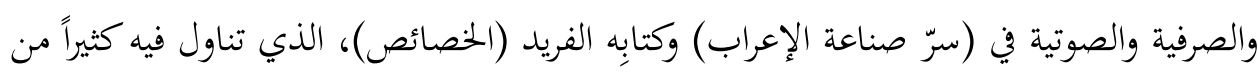

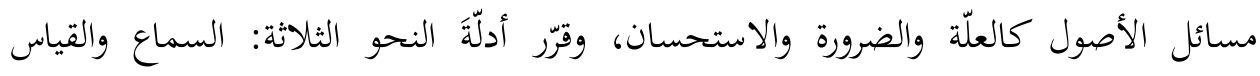

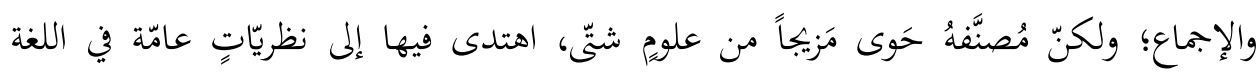

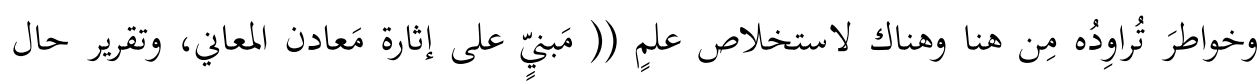

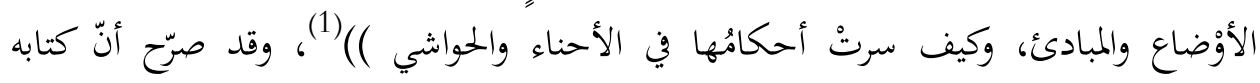

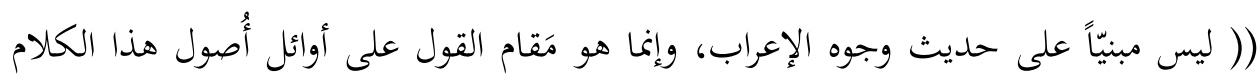

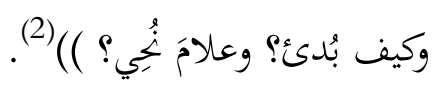

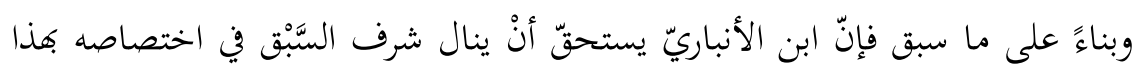

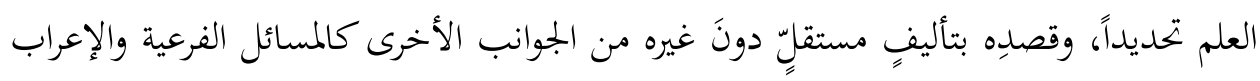

$$
\begin{aligned}
& \text { 1- الخصائص لابن جني 132. } \\
& \text { 2- نفسه 67/1. }
\end{aligned}
$$


والشواهد وغيرها مِن اهتمامات أغلب النحاة قبلَه وبعدَه، أمّا ما ذكره السيوطيّ -رحمه اللهـ- في

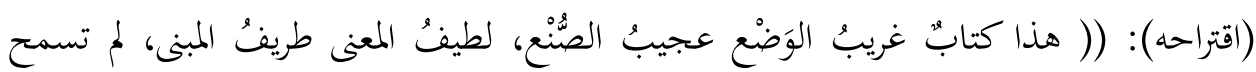

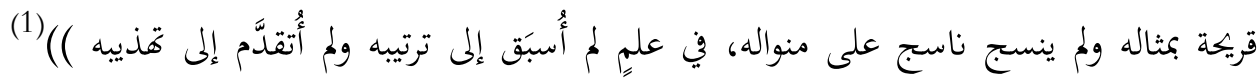

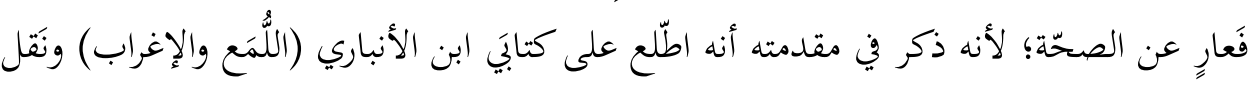

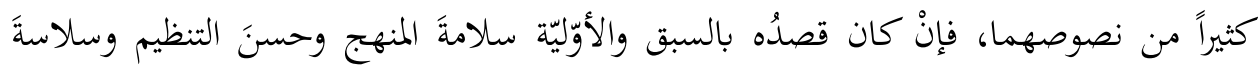

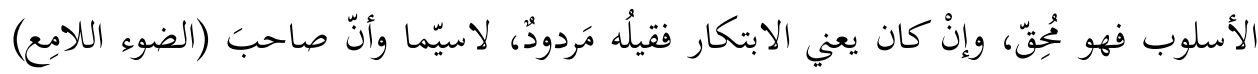

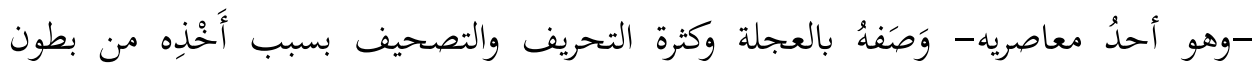

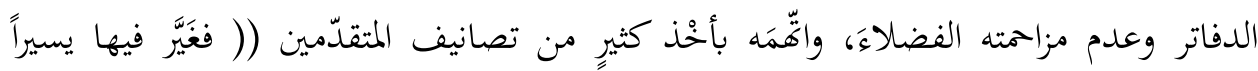

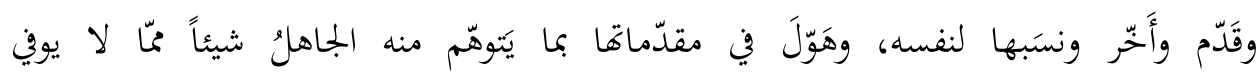

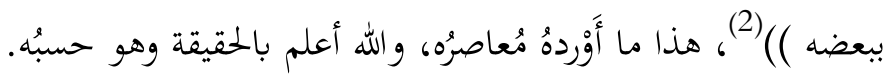

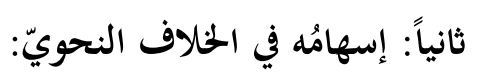

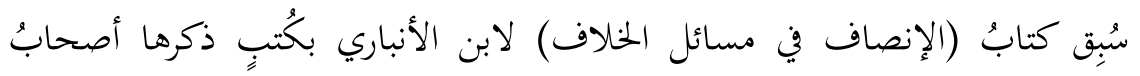

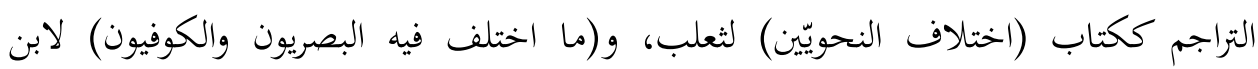

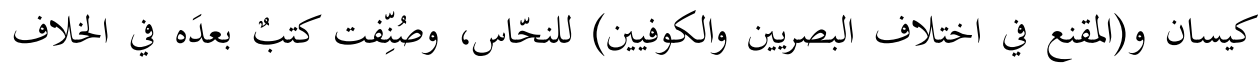

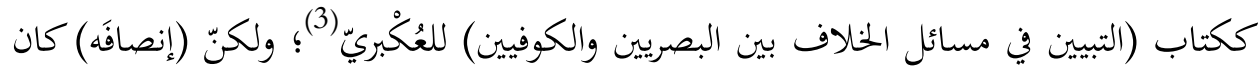

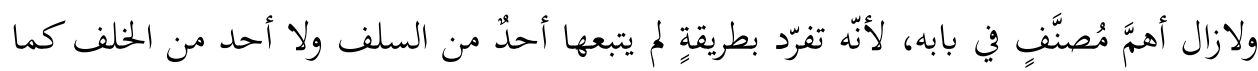

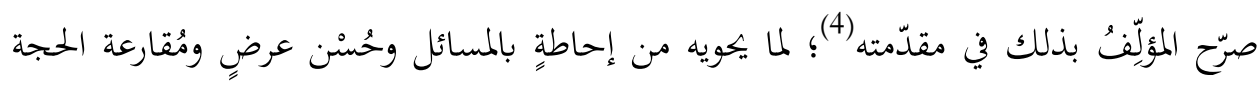

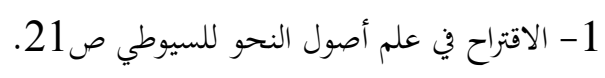

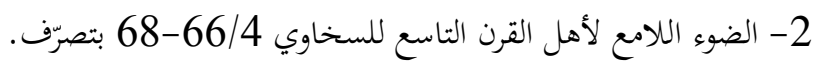

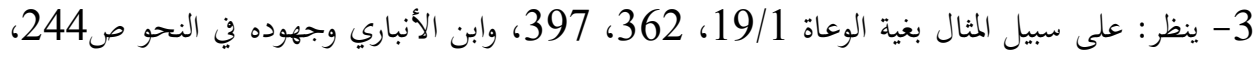

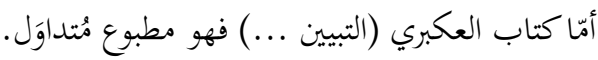

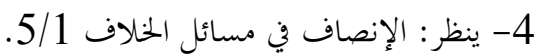


بالحجّة وإصدار الأحكام ... وغير ذلك من الأمور التي جعلتْه يَتفوّق على سابقيه، ويَقصُر عنه لاَحِقُوهُ؛ بل هم عالةُ عليه، وسأكتفي بالإشارة إلى مسألتين وَرَدَتَا في إنصافه هما:

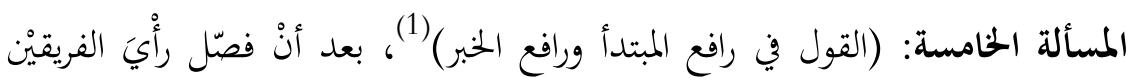
وحُجَجهما خرج برأيٍ توفيقيّ وتعليلٍ مَنطقيّ مَفادُه: (( والتحقيق فيه عندي أنْ يُقال: إنّ

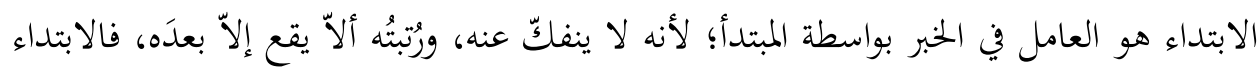

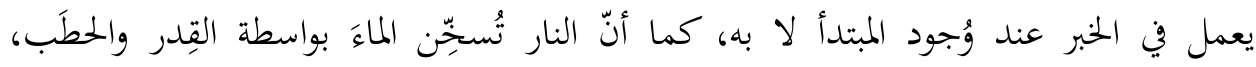

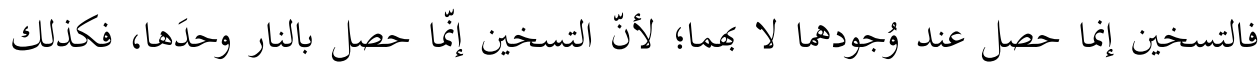

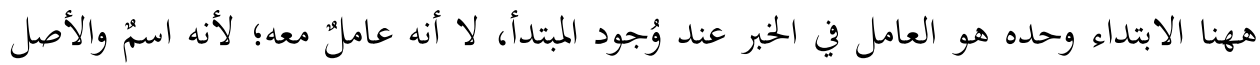

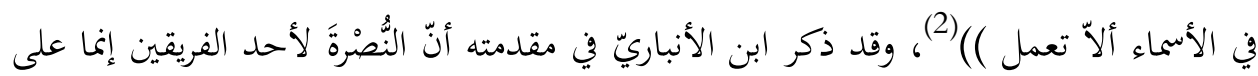

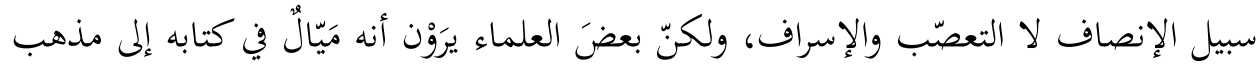
البصريين، بدليل أنه انتصر للكوفيين في سبع مسائل، ووافقَ البصريين في أربع عشرة ومائة مسألةٍ(3)، ولا عجب في ذلك فسِسلة مَشايخه في (نُزهته) التي ابتدأها بابن الشجري حتى فئي

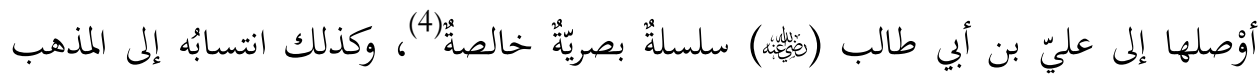

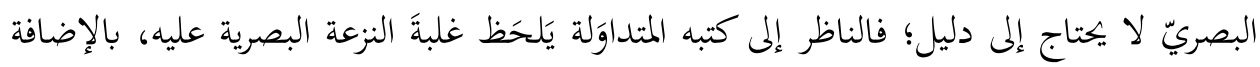

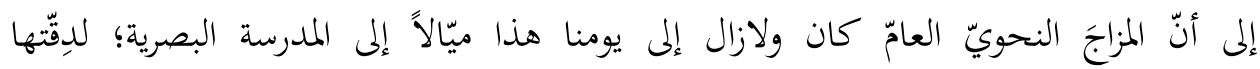

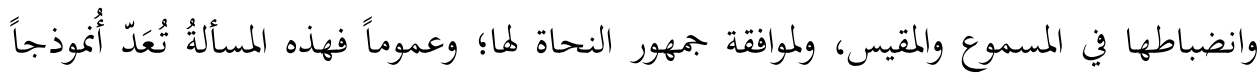
بارزاً على سلامَة عرضه وترتيبه للآراء والردود، وإبراز الحُججَج، وصَوْلاته وجَوْلاته في المسألة.

1 - الإنصاف في مسائل الخلاف 44/1-51

2- نفسه -46/1-47.

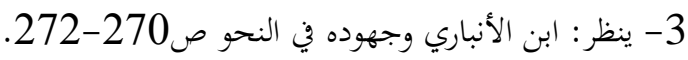

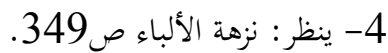


المسألة الستون: (القول في الفصل بين المضاف والمضاف إليه)(1) بعد أن استعرض

ابنُ الأنباري شواهدَ الكوفيين الشعرية والنثرية، وقراءةَ ابن عامر بالبناء لغير الفاعل في (زُِّّنَ) ورفع

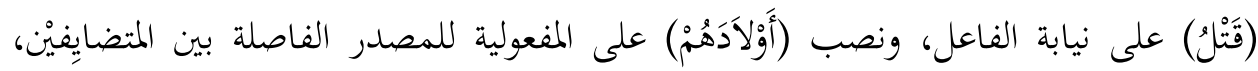

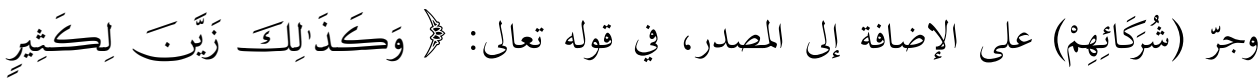

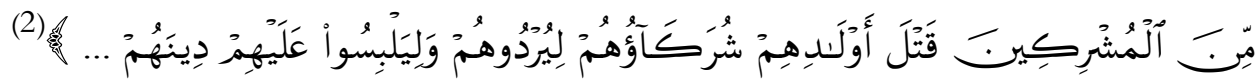
وبعد أنْ أَوْرَد حُججَهم، ردّ عليهم بما ارتضاه من أجوبة البصريين، ثمّ عقّب قائلاً: (( وأمّا قراءة

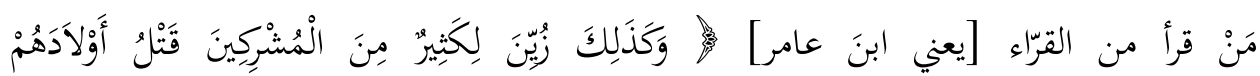

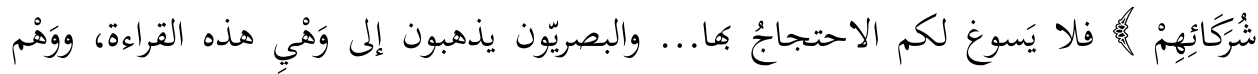

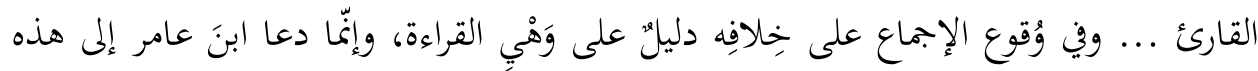

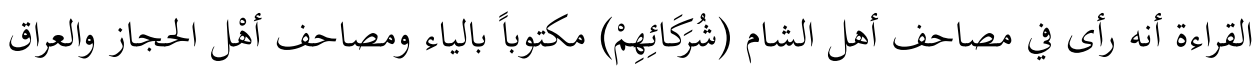

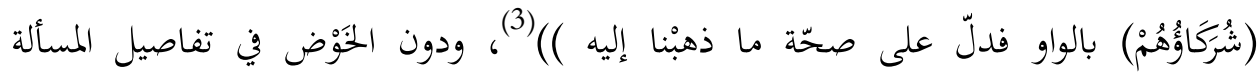

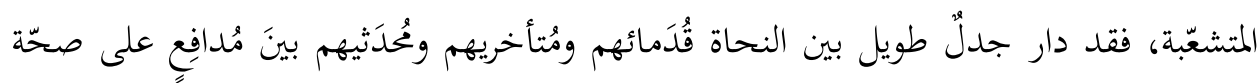

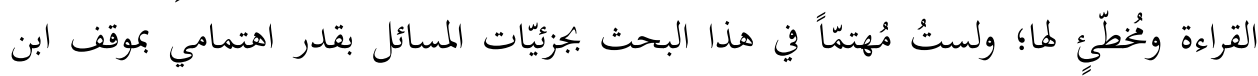

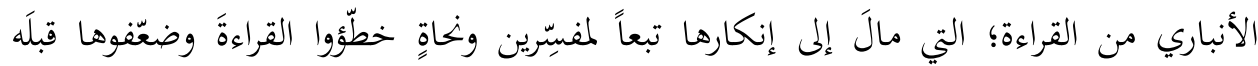

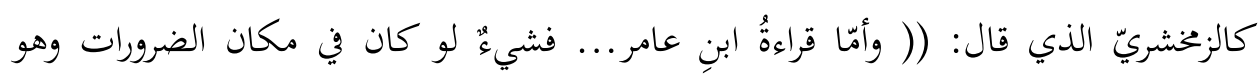

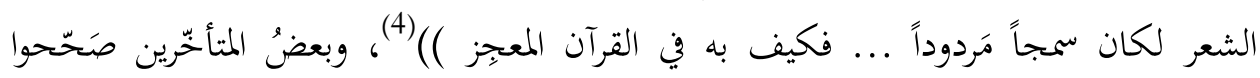

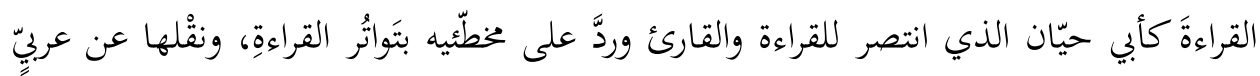
صريحٍ فصيح (5)؛ والغريب في الأمر أنّ ابنَ الأنباري نفسَه قرّر في الفصل الخامس من (لُمَعِه) في 1- ينظر: الإنصاف 427/2-436؛ وابن الأنباري وجهوده في النحو ص-301-303. 2- 2 - سورة الأنعام: 137. 3- الكشاف للزخشري 54/2.

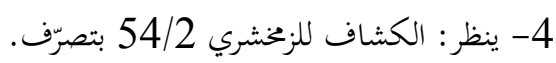

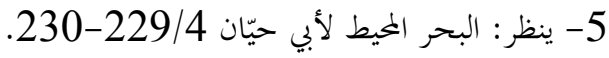


شرط نقل المتواتر: (( واعلم أنّ أكثر العلماء ذهبوا إلى أنّ شرط التواتر أنْ يبلْغ عددُ النقَّلة إلى لئل

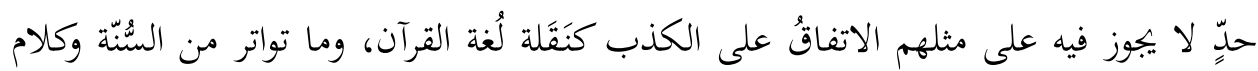

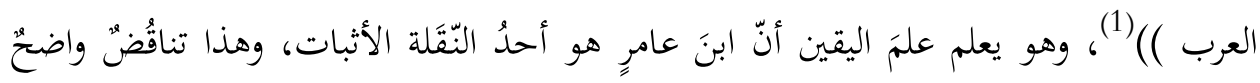
بين التنظير والتطبيق.

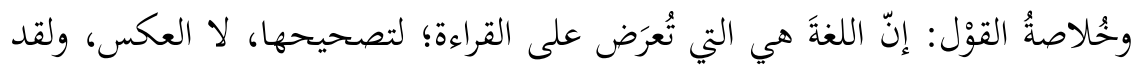

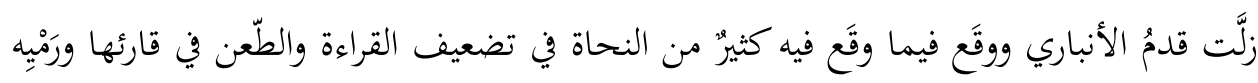

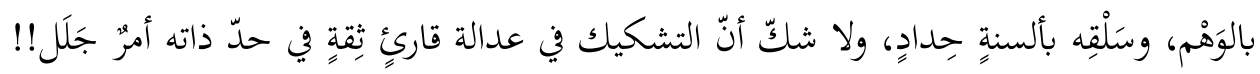

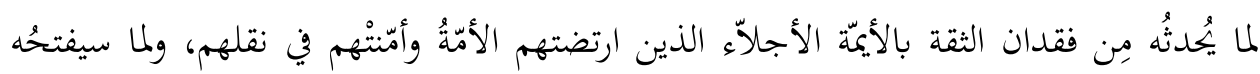

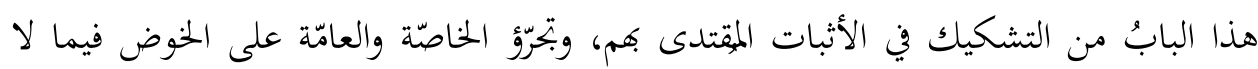

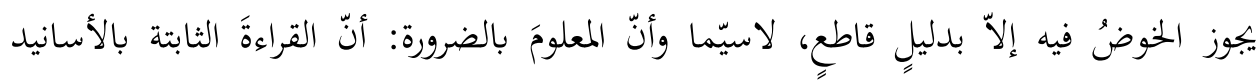

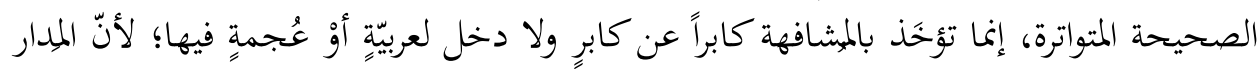

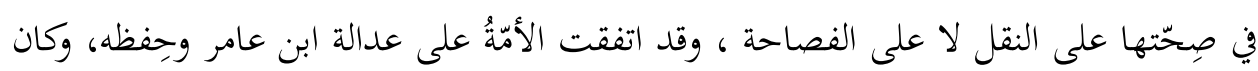

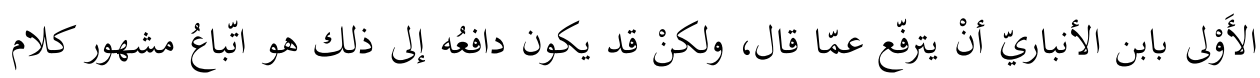

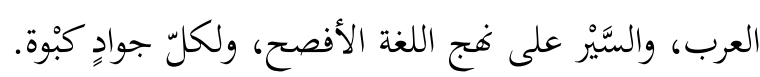

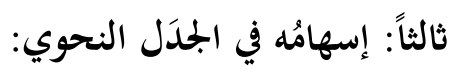

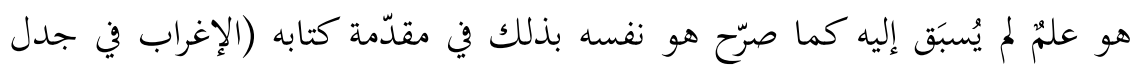

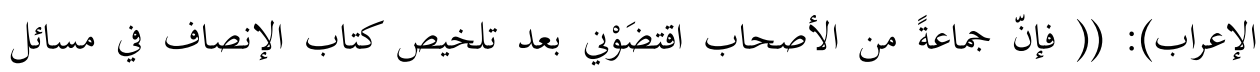

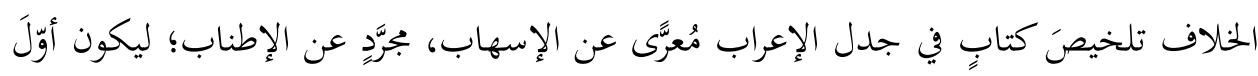

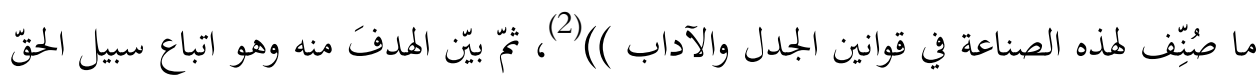

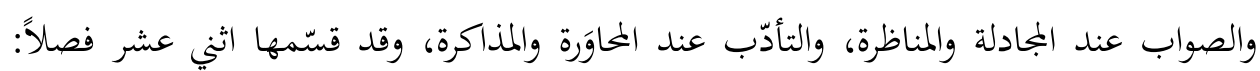

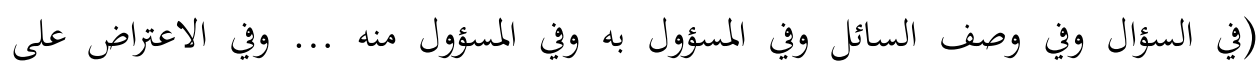

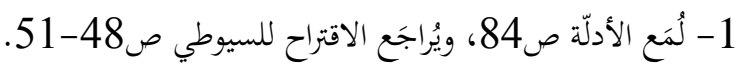

$$
\begin{aligned}
& \text { 2- الإغراب في جدل الإعراب ص35. }
\end{aligned}
$$


الاستدلال باستصحاب الحال وفي ترجيح الأدلّة)(1)، ولتبيين طريقته المنطقية الجلدلية في الكتاب أكتفي بنقل الفصل الخامس (في وصف المسؤول عنه): (( إعلم أنّ المسؤولَ عنه ينبغي أنْ يكون

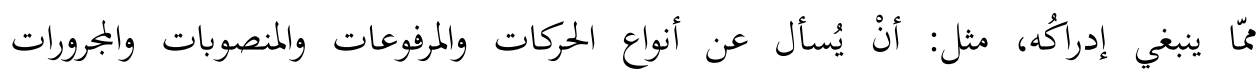

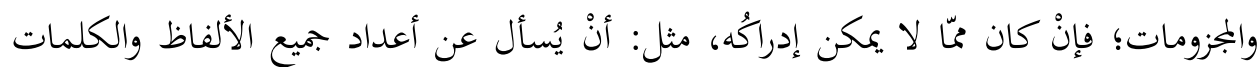
الدالّة على جميع المسميات كان فاسداً؛ لِتعذُّر إدراكه فلا يَستحقّ الجوابَ عنه )( (2).

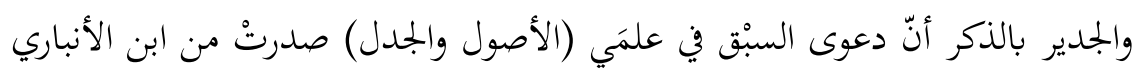
نفسه حين قال في (نزهته): (( ... فإنّ علوم الأدب ثمانية: النحو واللغة والتصريف والعَروض والقوافي وصنعة الشعر وأخبار العرب وأنساكم؟؛ وألحقننا بالعلوم الثمانية علميْن وَضعْناهما، وهما

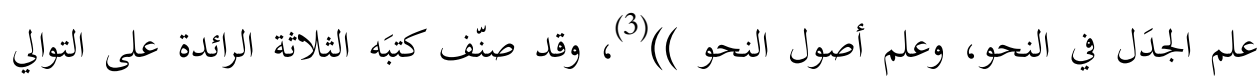

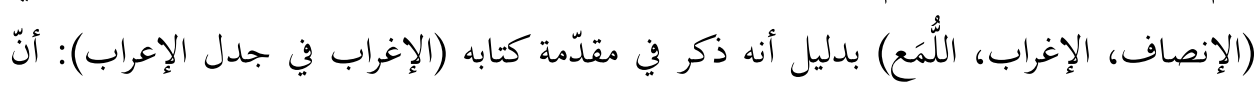
جماعةً من أصحابه بعد أن استحسنوا صَنيعَه في كتاب (الإنصاف في مسائل الخلاف) إقتضضونه

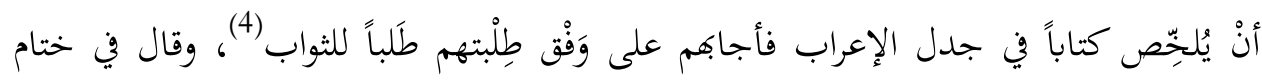

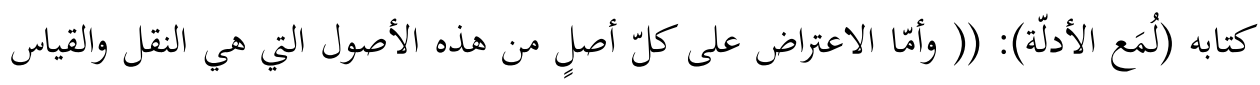

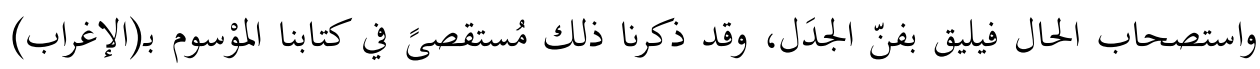
والله أعلم بالصواب ()(5) الخاتمة: ما أثبتهُ في هذا البحث لا يعدو أنْ يكون سطراً في مجلّد الإمام ابن الأنباري المزدحِم

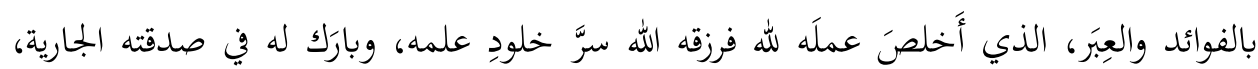

\begin{tabular}{|c|}
\hline 1- ينظر: نفسه ص35-36. \\
\hline 2- الإغراب في جدل الإعراب ص43. \\
\hline 3- نزهة الألبّاء ص84. \\
\hline 4- ينظر : ص35-36. \\
\hline 5- لمع الأدلّة ص143. \\
\hline
\end{tabular}




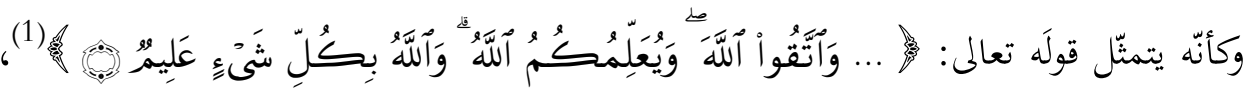
ولا أدّعي أني أضفتُ جديداً؛ لكنّي ركّزت على جوانب مِن العطاء في شخصيّه؛ لتكون مدرسةً

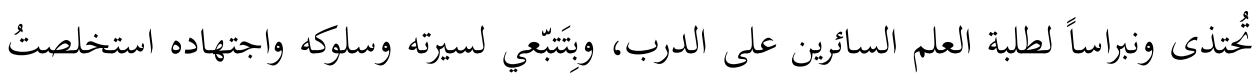
بعض الملاحظات الآتية: - م: - مُشاركتُه في علومٍ شتّى دليلٌ على سعة اطّلاعه، وتنوّع اهتماماته، واستيعابه لعلوم عصره. - اتّسمت بعضُ كتاباته في حقل النحو (بمعناه الواسع: النحو/ الصرف) وما يتعلّق به، بأهما كتابةٌ غيرُ تقليدية؛ فلم يتبع فيها خُطى أسلافه، مِن استعراض الأبواب النحوية المعروفة

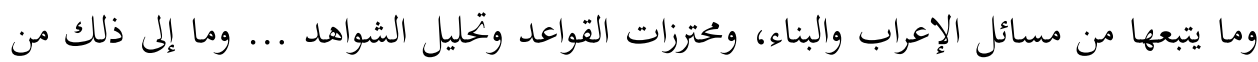

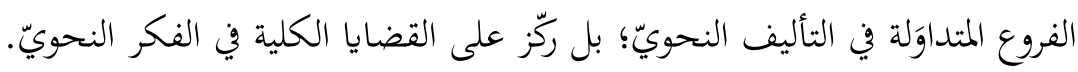
- يظهر تفرُده الحقيقيّ وإسهاماته النوعيّة في اهتمامه بجوانب سُبِّق إليها بإشاراتٍ

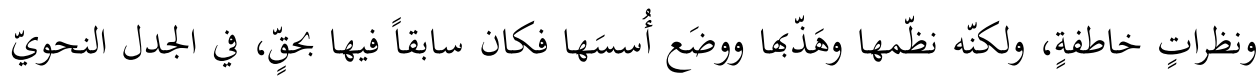

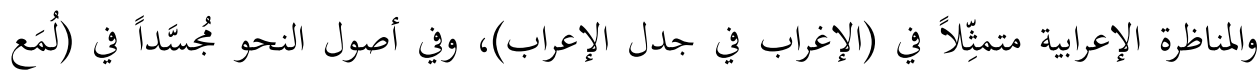
الأدلّة)، وفي الخلاف النحويّ الذي سطّه في أشهر كتبه وأنفعها على الإطلاق (الإنصاف في وليه

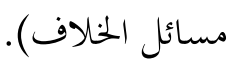
- يُعَدّ كتاباه (نزهة الألبّاء في طبقات الأدباء، وأسرار العربية) رائديْن في مجالهما، حيث اتّسم الأوّلُ بدقّة النقل وسهولة العبارة واختزال المعلومة، وتوثيق تراجم أيمّة العربيّة إلى عصره، والثاني تميّز بحُسن العرض القائم على السؤال المتوقَّع المشفوع بالجواب المنّاسب.

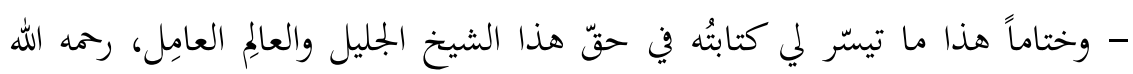
رحمةً واسعةًا

والحمد لله أوّلاً وآخراً. 


\section{قائمة المصادر والمراجع}

مصحف المدينة.

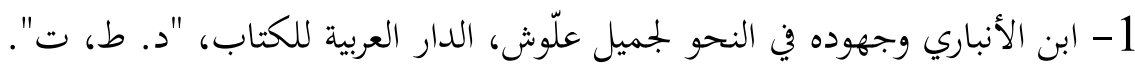

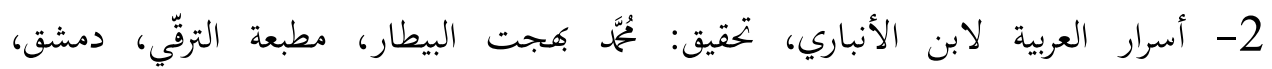

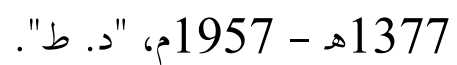

3- الأعلام لخير الدين الزركلي، الطبعة الثالثة، "د. د، تأد".

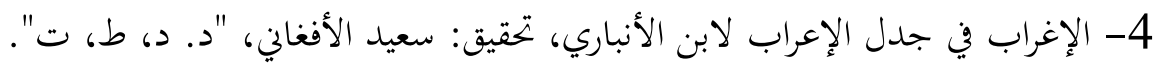

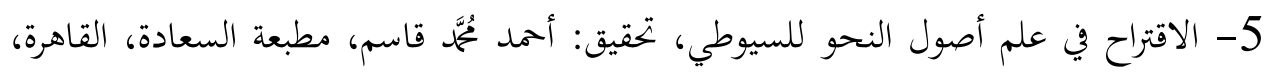

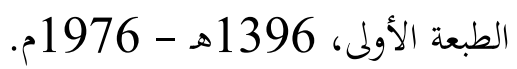
6- إنباه الرواة على أنباه النحاة للقفطي، تحقيق: يُحَّمَ أبو الفضل إبراهيم، دار الكتب المصرية،

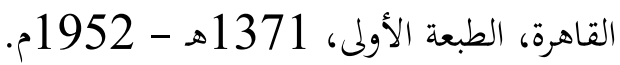

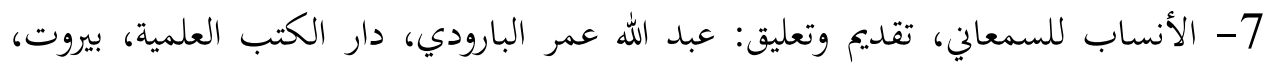
دار الجنان، الطبعة الأولى، 1408هـ - 1988م. 8- الإنصاف في مسائل الخلاف بين النحويين الكوفيين والبصريين لابن الأنباري، تحقيق: عُمَّمَ

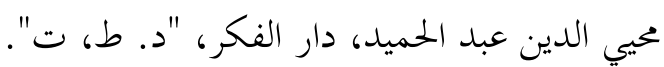
9- البحر المحيط (التفسير الكبير) لأبي حيّان، دار إحياء التراث العربي، بيروت، الطبعة الثانية، 1411

10 - البداية والنهاية لابن كثير، مكتبة المعارف، بيروت، ط: الثانية، 1977م.

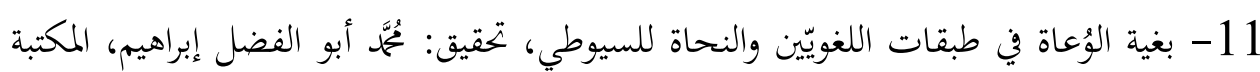

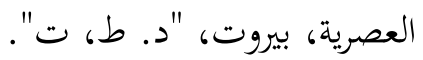


12- تاريخ الأدب العربي لكارل بروكلمان، ترجمة: رمضان عبد التوّاب، مراجعة الترجمة: السيد

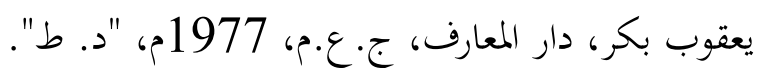
13- التبيين عن مذاهب النحويين البصريين والكوفيين لأبي البقاء العكبري، تحقيق: عبد الرحمن بن سليمان العثيمين، دار الغرب الإسلاميّ، بيروت، الطبعة الأولى، 1406هـ - 1486 1986م.

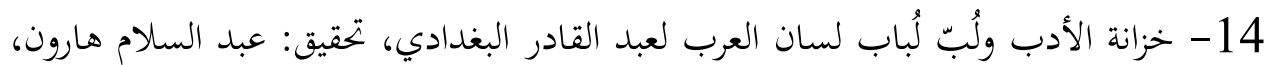

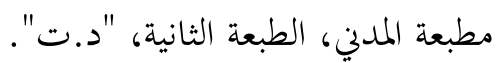
15- الخصائص لابن جنّ، تمقيق: تُمحَّة علي النجّار، دار الكتب المصرية، الطبعة الثانية، 1371 هـ - 1952م 16- دائرة المعارف الإسلامية: أُصدر بالألمانية والإنجليزية والفرنسية، نقلها إلى اللغة العربية: عُمَّمَ

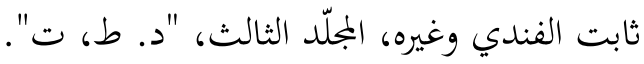
17- روضات الجنات في أحوال العلماء والسادات لمحمد باقر الخوانساري، تحقيق: أسد الله

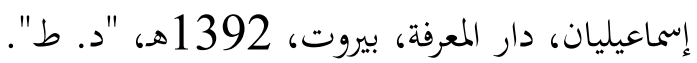
18- شرح ديوان المتبيّي لعبد الرحمن البرقوقي، دار الكتاب العربي، بيروت، 1407هـ - 1986م، "د. طرئ.

19 - الضوء اللامع لأهل القرن التاسع للسخاوي، دار مكتبة الحياة، بيروت، "د. ط، ته".

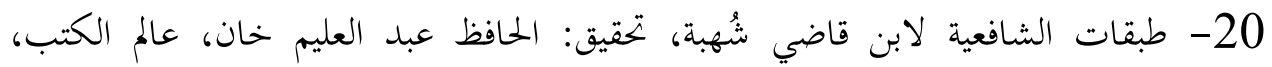
بيروت، الطبعة الأولى، 1407هـ - 1987م. 21- طبقات الشافعية الكبرى لتاج الدين السبكي، دار المعرفة، بيروت، الطبعة الثانية، "د.ت" التهات 22- غاية النهاية في طبقات القرّاء لابن الجزري، نشر: ج. برجستراسر، دار الكتب العلمية، بيروت، الطبعة الثالثة، 1402هـ - 1982م. 1982. 23- فوات الوفيات محمد بن شاكر الكتبي، تحقيق: إحسان عبّاس، دار الثقافة، بيروت،

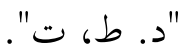
24- الكامل في التاريخ لابن الأثير، دار صادر، بيروت، 1966م، "د. ط". 
25- الكشاف عن حقائق التنزيل وعيون الأقاويل في وجوه التأويل لجار الله محمود الزخشري، دار الفكر، الطبعة الأولى، 1403هـ - 1983م. 26- كشف الظنون عن أسامي الكتب والفنون لحاجي خليفة، مكتبة المثنى، بيروت،

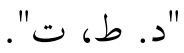
27- لُمَع الأدلّة لابن الأنباري، تحقيق: سعيد الأفغاني، "د. د، ط، ت".

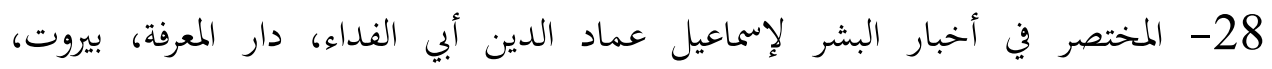

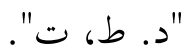
29- مرآة الجنان وعبرة اليقظان في معرفة ما يُعتبرك من حوادث الزمان لعبد الله اليافعي،

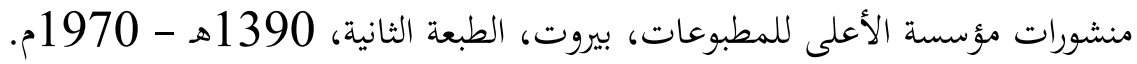
30- معجم البلدان لياقوت الحموي، تحقيق: فريد عبد العزيز الجندي، دار الكتب العلمية، بيروت، الطبعة الأولى، 1410هـ - 1990م. 1990. 31- معجم المؤلفين لعمر كحالة، مطبعة الترقي، دمشق، 1377هـ - 138 1958م، "د. ط" ط". 32- مقدّمة ابن خلدون لعبد الرحمن بن خلدون، دار إحياء التراث العربي، بيروت،

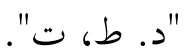
33- النجوم الزاهرة في ملوك مصر والقاهرة لابن تغري بردي، وزارة الثقافة والإرشاد القومي،

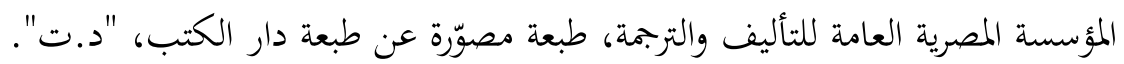
34- نزهة الألبّاء في طبقات الأدباء لابن الأنباري، تحقيق: عُمَّمَ أبو الفضل إبراهيم، دار الفكر

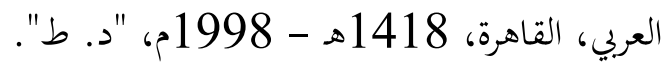
35- هدية العارفين، أسماء المؤلفّين، آثار المصنّفين لإسماعيل البغدادي، منشورات مكتبة المثنّى، طبع باستانبول، 1951م، وأُعيد طبعُه بالأوفست. 36- وفيات الأعيان وأنباء أبناء الزمان لأحمد بن خلّكانان، تحقيق: إحسان عبّاس، دار صادر،

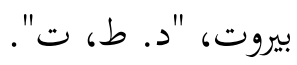

